\title{
Annual greenhouse gas budget for a bog ecosystem undergoing restoration by rewetting
}

\author{
Sung-Ching Lee ${ }^{1}$, Andreas Christen ${ }^{1}$, Andrew T. Black ${ }^{2}$, Mark S. Johnson ${ }^{3,4}$, Rachhpal S. Jassal ${ }^{2}$, Rick Ketler ${ }^{1}$, \\ Zoran Nesic ${ }^{1,2}$, and Markus Merkens ${ }^{5}$ \\ ${ }^{1}$ Department of Geography/Atmospheric Science Program, University of British Columbia, Vancouver, Canada \\ ${ }^{2}$ Faculty of Land and Food Systems, University of British Columbia, Vancouver, Canada \\ ${ }^{3}$ Institute of Resources, Environment and Sustainability, University of British Columbia, Vancouver, Canada \\ ${ }^{4}$ Department of Earth, Ocean and Atmospheric Sciences, University of British Columbia, Vancouver, Canada \\ ${ }^{5}$ Parks, Planning and Environment Department, Metro Vancouver, Vancouver, Canada \\ Correspondence to: Sung-Ching Lee (sungching.lee@geog.ubc.ca)
}

Received: 21 October 2016 - Discussion started: 1 November 2016

Revised: 2 May 2017 - Accepted: 2 May 2017 - Published: 8 June 2017

\begin{abstract}
Many peatlands have been drained and harvested for peat mining, agriculture, and other purposes, which has turned them from carbon (C) sinks into $\mathrm{C}$ emitters. Rewetting of disturbed peatlands facilitates their ecological recovery and may help them revert to carbon dioxide $\left(\mathrm{CO}_{2}\right)$ sinks. However, rewetting may also cause substantial emissions of the more potent greenhouse gas (GHG) methane $\left(\mathrm{CH}_{4}\right)$. Our knowledge of the exchange of $\mathrm{CO}_{2}$ and $\mathrm{CH}_{4}$ following rewetting during restoration of disturbed peatlands is currently limited. This study quantifies annual fluxes of $\mathrm{CO}_{2}$ and $\mathrm{CH}_{4}$ in a disturbed and rewetted area located in the Burns Bog Ecological Conservancy Area in Delta, BC, Canada. Burns Bog is recognized as the largest raised bog ecosystem on North America's west coast. Burns Bog was substantially reduced in size and degraded by peat mining and agriculture. Since 2005, the bog has been declared a conservancy area, with restoration efforts focusing on rewetting disturbed ecosystems to recover Sphagnum and suppress fires. Using the eddy covariance (EC) technique, we measured year-round (16 June 2015 to 15 June 2016) turbulent fluxes of $\mathrm{CO}_{2}$ and $\mathrm{CH}_{4}$ from a tower platform in an area rewetted for the last 8 years. The study area, dominated by sedges and Sphagnum, experienced a varying water table position that ranged between 7.7 (inundation) and $-26.5 \mathrm{~cm}$ from the surface during the study year. The annual $\mathrm{CO}_{2}$ budget of the rewetted area was $-179 \pm 26.2 \mathrm{~g} \mathrm{CO}_{2}-\mathrm{C} \mathrm{m}^{-2} \mathrm{yr}^{-1}$ $\left(\mathrm{CO}_{2}\right.$ sink $)$ and the annual $\mathrm{CH}_{4}$ budget was $17 \pm 1.0 \mathrm{~g} \mathrm{CH}_{4}-$ $\mathrm{C} \mathrm{m}^{-2} \mathrm{yr}^{-1}\left(\mathrm{CH}_{4}\right.$ source $)$. Gross ecosystem productivity
\end{abstract}

(GEP) exceeded ecosystem respiration $\left(R_{\mathrm{e}}\right)$ during summer months (June-August), causing a net $\mathrm{CO}_{2}$ uptake. In summer, high $\mathrm{CH}_{4}$ emissions (121 $\mathrm{mg} \mathrm{CH}_{4}-\mathrm{C} \mathrm{m}^{-2}$ day ${ }^{-1}$ ) were measured. In winter (December-February), while roughly equal magnitudes of GEP and $R_{\mathrm{e}}$ made the study area $\mathrm{CO}_{2}$ neutral, very low $\mathrm{CH}_{4}$ emissions $\left(9 \mathrm{mg} \mathrm{CH}_{4}-\mathrm{C} \mathrm{m}^{-2}\right.$ day $\left.^{-1}\right)$ were observed. The key environmental factors controlling the seasonality of these exchanges were downwelling photosynthetically active radiation and $5 \mathrm{~cm}$ soil temperature. It appears that the high water table caused by ditch blocking suppressed $R_{\mathrm{e}}$. With low temperatures in winter, $\mathrm{CH}_{4}$ emissions were more suppressed than $R_{\mathrm{e}}$. Annual net $\mathrm{GHG}$ flux from $\mathrm{CO}_{2}$ and $\mathrm{CH}_{4}$ expressed in terms of $\mathrm{CO}_{2}$ equivalents $\left(\mathrm{CO}_{2}\right.$ eq. $)$ during the study period totalled $-22 \pm 103.1 \mathrm{~g} \mathrm{CO}_{2}$ eq. $\mathrm{m}^{-2} \mathrm{yr}^{-1}$ (net $\mathrm{CO}_{2}$ eq. sink) and $1248 \pm 147.6 \mathrm{~g} \mathrm{CO}_{2}$ eq. $\mathrm{m}^{-2} \mathrm{yr}^{-1}$ (net $\mathrm{CO}_{2}$ eq. source) by using 100- and 20-year global warming potential values, respectively. Consequently, the ecosystem was almost $\mathrm{CO}_{2}$ eq. neutral during the study period expressed on a 100year time horizon but was a significant $\mathrm{CO}_{2}$ eq. source on a 20-year time horizon.

\section{Introduction}

Wetland ecosystems play a disproportionately large role in the global carbon (C) cycle compared to the surface area they occupy. Wetlands cover only 6-7\% of the Earth's terrestrial 
surface (Lehner and Döll, 2004; Mitsch et al., 2010) but C storage in wetlands has been estimated to be up to $450 \mathrm{GtC}$ or approximately $20 \%$ of the total $\mathrm{C}$ storage in the terrestrial biosphere (Bridgham et al., 2006; Lal, 2008; Wisniewski and Sampson, 2012). However, they emit significant quantities of methane $\left(\mathrm{CH}_{4}\right)$, a powerful greenhouse gas $(\mathrm{GHG})$. Wetlands are responsible for $30 \%$ of all global $\mathrm{CH}_{4}$ emissions (Bergamaschi et al., 2007; Bloom et al., 2010; Ciais et al., 2013) due to anaerobic microbial decomposition (Aurela et al., 2001; Rinne et al., 2007). Peatlands are the most widespread of all wetland types in the world, representing 50 to $70 \%$ of global wetlands (Roulet, 2000; Yu et al., 2010). Peatlands around the world sequester around $50 \mathrm{~g} \mathrm{CO}_{2}-\mathrm{C} \mathrm{m}^{-2} \mathrm{yr}^{-1}$ (Roulet et al., 2007; Christensen et al., 2012; Humphreys et al., 2014; McVeigh et al., 2014; Peichl et al., 2014; Pelletier et al., 2015) and emit around $12 \mathrm{~g} \mathrm{CH}_{4}-\mathrm{C} \mathrm{m}^{-2} \mathrm{yr}^{-1}$ (Abdalla et al., 2016; Brown et al., 2014; Jackowicz-Korczynski et al., 2010; Lai et al., 2014; Urbanová et al., 2013). Furthermore, it has been shown that it is crucial to include peatlands in the modelling and analysis of the global $\mathrm{C}$ cycle (Frolking et al., 2013; Kleinen et al., 2010; Wania et al., 2009).

Many peatlands have been harvested and continue to be disturbed by the extraction of peat for horticultural use and conversion to agriculture as well as other purposes. In the case of Burns Bog, peat was also used for fire bombs during World War II (Cowen, 2015). Generally, during harvesting, the surface vegetation is removed, and then wetlands are drained by a network of ditches (Price and Waddington, 2000; Waddington and Roulet, 2000). When no longer economical, many harvested peatlands are abandoned and kept at artificially low water tables due to the drainage ditches. This environmental condition limits the disturbed and abandoned peatlands ability to return to their prior state. Drainage results in increased oxidation in peat soils, which then can become a strong source of $\mathrm{CO}_{2}$ (Langeveld et al., 1997; Petrescu et al., 2015; Joosten, 2012). Additionally, degraded peat increases the risk of peatland fires, which could consequently cause significant $\mathrm{CO}_{2}$ emissions (Gaveau et al., 2014; Page et al., 2002; van der Werf et al., 2004). These consequences could be worse if nothing is done after the peat extraction. Therefore, and for reasons of conservation ecology (unique habitat), disturbed peatlands may be restored.

Restoration efforts typically rely on elevating the water table and managing vegetation. The water table depth and the amount of vegetation are the most important factors affecting land-atmosphere $\mathrm{C}$ exchange. Rewetting by ditch blocking can have an immediate impact on the $\mathrm{C}$ exchange between the peatland surface and the atmosphere (Limpens et al., 2008). Rewetting has strong direct and indirect effects on $\mathrm{CO}_{2}$ and $\mathrm{CH}_{4}$ fluxes. Raising the water level has been found to suppress the $\mathrm{CO}_{2}$ efflux from the soil and result in an increase in net $\mathrm{CO}_{2}$ uptake by native bog vegetation (Komulainen et al., 1999). $\mathrm{CH}_{4}$ emissions from rewetted sections in a bog in Finland were 3 times higher than the release from the disturbed and dry area (Tuittila et al., 2000). Another study found similar rates of $\mathrm{CH}_{4}$ production in disturbed and restored wetlands in the southern United States (Schipper and Reddy, 1994). Revegetation of degraded peat leads to faster re-establishment of peat formation that can have significant effects on $\mathrm{C}$ exchange. However, the increased aboveand below-ground biomass of plants and litter enhances organic matter oxidation, which raises $\mathrm{CO}_{2}$ emissions (Finér and Laine, 1998; Minkkinen and Laine, 1998). In other studies, re-establishing the conditions permitting peat formation also initially increased $\mathrm{CH}_{4}$ emissions, but the $\mathrm{C}$ exchange did not reach the level of seasonal emissions from pristine peatlands (Crill et al., 1992; Dise et al., 1993; Shannon and White, 1994).

Very few studies provide continuous, year-round measurements to determine how restored and rewetted peatland ecosystems recover in terms of their productivity and GHG exchange. It remains unclear when, or even if, restored peatland ecosystems could show a similar magnitude of $\mathrm{C}$ fluxes as in pristine (undisturbed) peatland ecosystems. Furthermore, most investigations focusing on GHG exchange of restored peatlands only measured $\mathrm{CO}_{2}$ and/or $\mathrm{CH}_{4}$ fluxes during short periods, e.g. the growing season. There are few studies that measured continuously and year-round fluxes (Anderson et al., 2016; Järveoja et al., 2016; Knox et al., 2015; Richards and Craft, 2015; Strack and Zuback, 2013), relying instead on sporadic, or repeating, chamber measurements, which are difficult to upscale to annual totals.

In this study, we (a) quantified seasonal and annual $\mathrm{CO}_{2}$ and $\mathrm{CH}_{4}$ fluxes, using the eddy covariance (EC) technique, in a disturbed ecosystem that is representative of areas subject to recent restoration efforts (ditch blocking for the last 8 years); (b) identified key environmental controls and their effects on $\mathrm{CO}_{2}$ and $\mathrm{CH}_{4}$ fluxes; and (c) quantified whether the study ecosystem is net source or sink of $\mathrm{C}$ and its net climate forcing at different timescales by considering the global warming potential (GWP) of $\mathrm{CO}_{2}$ and $\mathrm{CH}_{4}$.

\section{Study area}

Burns Bog in Delta, BC, on Canada's Pacific coast, is part of a remnant peatland ecosystem that is recognized as the largest raised bog ecosystem (2042 ha) on North America's west coast. During the last century, it was significantly disturbed as a result of it being used for housing, peat mining, and agriculture (Metro Vancouver, 2007). The Burns Bog Ecological Conservancy Area (BBECA) was established in 2005 to conserve this large coastal raised bog and restore ecological integrity to the greatest extent possible. Christen et al. (2016) measured summertime $\mathrm{CO}_{2}$ and $\mathrm{CH}_{4}$ exchanges using primarily chamber systems in several plots representative of disturbed areas of the BBECA, where some plots were rewetted and others were not. The study found substantial emissions of $\mathrm{CH}_{4}$ primarily in recently rewetted plots, with the highest emissions associated with high water tables. Nev- 
ertheless, a significant spatial and temporal variability was found between and within plots. In order to constrain these emission estimates, it was suggested to extend the year-round monitoring of $\mathrm{CO}_{2}$ and $\mathrm{CH}_{4}$ exchanges using $\mathrm{EC}$ technique to provide spatially more representative fluxes at a recently rewetted plot.

The current study site is located in a harvested, disturbed, and rewetted area in the centre of the BBECA $\left(122^{\circ} 59^{\prime} 5.60^{\prime \prime} \mathrm{W}, 49^{\circ} 07^{\prime} 45.59^{\prime \prime} \mathrm{N}\right.$; WGS-84) with dimensions of $400 \mathrm{~m}$ by $250 \mathrm{~m}$ (Fig. 1). The field is surrounded by a windbreak to the west and an abandoned (now blocked) drainage ditch to the north (see Figs. S1 and S2 in the Supplement). The study area was harvested between 1957 and 1963 using the Atkins-Durbrow hydropeat method to remove the peat (Heathwaite and Göttlich, 1993). In 2007, the study site was rewetted via ditch blocking using dams built with plywood and using wooden stakes as bracing (Howie et al., 2009). Based on the weather data for 1981 to 2010 from the closest Environment Canada weather station, Vancouver International Airport, the average annual temperature was $10.4^{\circ}$ and average annual precipitation was $1189 \mathrm{~mm}$. Following rewetting, water table height (WTH) in the study area fluctuates between $30 \mathrm{~cm}$ above ground and $30 \mathrm{~cm}$ below ground over the year. In all years since rewetting started in 2007, water table positions were lower in late summer and early fall and high all winter and spring. WTH decreases steadily between June and September. In September and October, a water table rise due to the increase in precipitation and reduced evapotranspiration (ET) (Fig. 2) as a consequence of reduced available energy and senescence of sedges was observed, which is similar to water table observations in other temperate wetlands (Lafleur et al., 2005; Rydin et al., 2013). The depth of peat at the study site is $5.83 \mathrm{~m}$. A silty clay layer is located below the peat layer (Chestnutt, 2015). The plant communities in the study ecosystem are dominated by Sphagnum spp. and Rhynchospora alba. The average height of the vegetation during the growing season is about $0.3 \mathrm{~m}$ (Madrone Consultants Ltd., 1999). Plants are separated by shallow open water pools, some of them populated by algae developing. Birch trees are dispersed and appear to be growing on the remnants of baulks but none of them was taller $2 \mathrm{~m}$. Sphagnum covers over $25 \%$ of the surface inside the study area (Hebda et al., 2000). The area of the open water ponds was estimated to be about $20 \%$ of the surface in summer by aerial photo.

\section{Materials and methods}

\subsection{Climate measurements}

Weather variables were continuously measured in order to determine climatic controls of $\mathrm{CO}_{2}$ and $\mathrm{CH}_{4}$ fluxes. Four components of radiation (shortwave, longwave, incoming, and outgoing) were continuously measured by a four-

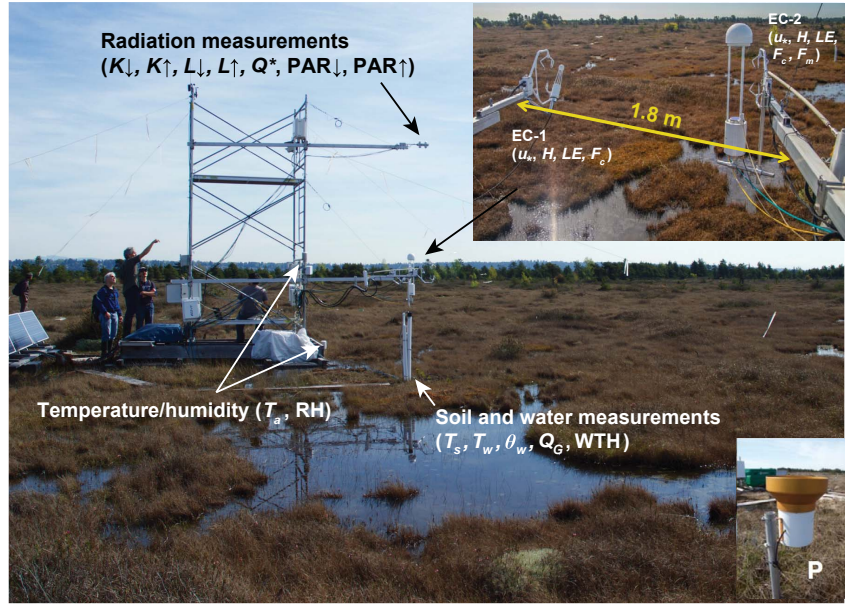

Figure 1. Flux tower on floating platform with EC-1 and EC-2 systems facing south and instruments that measured climate variables indicated (friction velocity $\left(u_{*}\right)$, sensible heat flux $(H)$, latent heat flux (LE), $\mathrm{CO}_{2}$ flux (NEE), $\mathrm{CH}_{4}$ flux $\left(F_{\mathrm{m}}\right)$, incoming shortwave radiation $(K \downarrow)$, outgoing shortwave radiation $(K \uparrow)$, incoming longwave radiation $(L \downarrow)$, outgoing longwave radiation $(L \uparrow)$, net all-wave radiation $\left(Q^{*}\right)$, incoming PAR (PAR $\downarrow$ ), outgoing PAR (PAR $\uparrow)$, air temperature $\left(T_{\mathrm{a}}\right)$, relative humidity $(\mathrm{RH})$, soil temperature $\left(T_{\mathrm{S}}\right)$, water temperature $\left(T_{\mathrm{W}}\right)$, soil water content $\left(\theta_{\mathrm{W}}\right)$, soil heat flux $\left(Q_{G}\right)$, water table height (WTH), and precipitation $(P)$ ).

component net radiometer (CNR1, Kipp and Zonen, Delft, Holland) on top of the tower. Two quantum sensors (LI-190, LI-COR Inc., Lincoln, NE, USA) measured incoming and outgoing photosynthetically active radiation (PAR). Precipitation was measured with an unheated tipping bucket rain gauge (TR-525M, Texas Electronics, Dallas, TX, USA) at $1 \mathrm{~m}$ height, $10 \mathrm{~m}$ north of the tower. Air temperature $\left(T_{\mathrm{a}}\right)$ and relative humidity $(\mathrm{RH})$ were measured at the heights of 2.0 and $0.3 \mathrm{~m}$ (HMP-35 A, Vaisala, Finland), and soil thermocouples (type $\mathrm{T}$ ) were recording soil and water temperatures at the depths of $0.05,0.10$, and $0.50 \mathrm{~m}\left(T_{\mathrm{s}, 5 \mathrm{~cm}}, T_{\mathrm{s}, 10 \mathrm{~cm}}\right.$, and $\left.T_{\mathrm{s}, 50 \mathrm{~cm}}\right)$. A pressure transducer (CS400, Campbell Scientific) was installed on 28 July 2015 in an observation well west of the tower to continuously measure WTH for the remainder of the study period. A soil volumetric water content $\left(\theta_{\mathrm{w}}\right)$ sensor (CS616, Campbell Scientific) was inserted vertically to measure integrated $\theta_{\mathrm{w}}$ from the surface to a depth of $0.30 \mathrm{~m}$.

\subsection{Eddy-covariance measurements}

Over the entire annual study period, from 16 June 2015 to 15 June 2016, a long-term eddy covariance system (EC1) was operated on a floating scaffold tower (Fig. 1) at a height of $1.8 \mathrm{~m}$ (facing south). The EC-1 system consisted of an ultrasonic anemometer-thermometer (CSAT-3, Campbell Scientific) and an open-path $\mathrm{CO}_{2}-\mathrm{H}_{2} \mathrm{O}$ infrared gas analyzer (IRGA, LI-7500, LI-COR Inc.). The path separation 

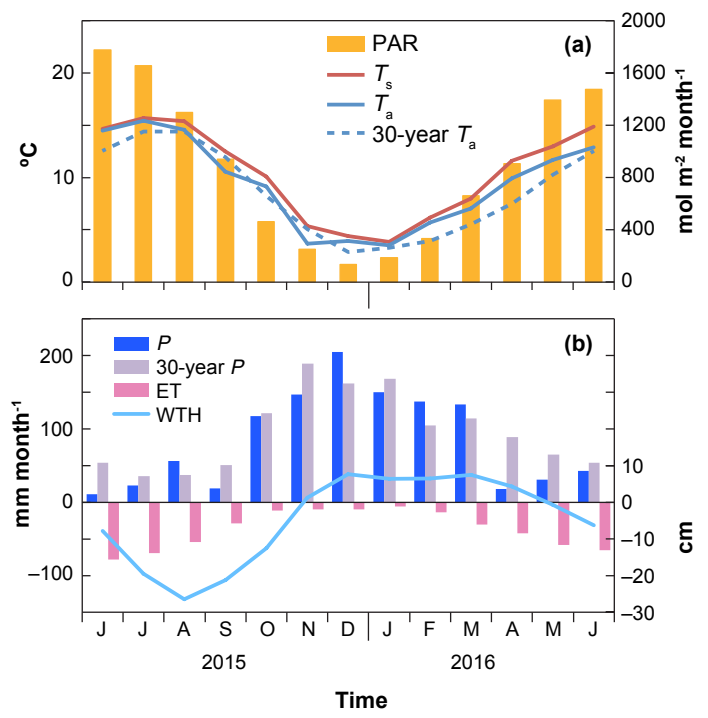

Figure 2. The annual course of weather variables $\left(T_{\mathrm{a}}, T_{\mathrm{S}}, P\right.$, and PAR), ET, and WTH. The 30-year climate normals (30-year $T_{\mathrm{a}}$ and $P$ ) were measured at Vancouver International Airport (data: Environment Canada).

between CSAT- 3 and LI-7500 was $5 \mathrm{~cm}$. The CSAT-3 measured the longitudinal, transverse, and vertical components of the wind vector and sonic temperature and output data at $10 \mathrm{~Hz}$. The IRGA measured water vapour density $\left(\rho_{\mathrm{v}}\right)$ and $\mathrm{CO}_{2}$ density $\left(\rho_{\mathrm{c}}\right)$ at $10 \mathrm{~Hz}$. The $10 \mathrm{~Hz}$ data from both instruments were sampled on a data logger (CR1000, Campbell Scientific) and processed fluxes of $\mathrm{CO}_{2}$ (net ecosystem exchange, NEE) were calculated in post-processing of $30 \mathrm{~min}$ data blocks following the procedures documented in Crawford et al. (2013).

An additional, independent EC system (EC-2) was added on 10 June 2015 to measure $\mathrm{CH}_{4}$ fluxes. The EC-2 system was also located at a height of $1.8 \mathrm{~m}, 1.8 \mathrm{~m}$ to the west of EC-1, and faced south (Fig. 1). EC-2 consisted of a similar ultrasonic anemometer-thermometer (CSAT-3, Campbell Scientific, $20 \mathrm{~Hz}$ ), an enclosed-path $\mathrm{H}_{2} \mathrm{O}-\mathrm{CO}_{2}$ IRGA (LI7200 , LI-COR Inc., $20 \mathrm{~Hz}$ ) and an open-path gas analyzer to measure the partial density of $\mathrm{CH}_{4}\left(\rho_{\mathrm{m}}\right)$ (LI-7700, LICOR Inc., $20 \mathrm{~Hz}$ ). The northward separation of LI-7200 was $20 \mathrm{~cm}$. The northward separation of LI-7700 was $40 \mathrm{~cm}$ and eastward separation of LI-7700 was $20 \mathrm{~cm}$. Data from EC-2 were collected by an analyzer interface unit (LI-7550, LICOR Inc.) and processed on site. Fluxes of $\mathrm{CH}_{4}\left(F_{\mathrm{m}}\right)$ were processed in advanced mode using EddyPro ${ }^{\circledR}$ (V6.1.0, LICOR Inc.) with a missing sample allowance of $30 \% . F_{\mathrm{m}}$ data were quality checked using the flagging system proposed by Foken et al. (2004).

\subsection{Gap-filling algorithms}

Some gaps in climate and flux measurements are unavoidable due to challenging weather and low-light situations (the station was solar powered) and need to be filled in for estimating seasonal and annual fluxes. Gaps in the climate data $(<1 \%$ of the year) were filled using measurements at nearby climate stations. Small gaps $(<60 \mathrm{~min})$ of missing $\mathrm{CO}_{2}, \mathrm{H}_{2} \mathrm{O}$, and $\mathrm{CH}_{4}$ fluxes were filled by linear interpolation. Longer gaps in $\mathrm{H}_{2} \mathrm{O}$ fluxes were filled with the online tool developed by the Max Planck Institute for Biogeochemistry in Jena, Germany. This tool uses the look-up table method documented in Falge et al. (2001) and Reichstein et al. (2005). Longer gaps in $\mathrm{CO}_{2}$ and $\mathrm{CH}_{4}$ fluxes were filled using empirical relationships between $\mathrm{CO}_{2}$ or $\mathrm{CH}_{4}$ fluxes and environmental variables. Two years (from July 2014 to June 2016) of measurements of $\mathrm{CO}_{2}$ fluxes were used for modelling ecosystem respiration $\left(R_{\mathrm{e}}\right)$ and gross ecosystem productivity (GEP) to achieve better statistical relationships. Since there were two EC systems running with redundant fluxes of $\mathrm{CO}_{2}$, the sensitivity of different combinations of data (EC-1 vs. EC-2 or using an average of the two) has been explored in Lee et al. (2016). For the data presented in this study, $\mathrm{CO}_{2}$ fluxes, $\mathrm{H}$, latent heat flux from $\mathrm{EC}-1$, and $\mathrm{CH}_{4}$ fluxes from $\mathrm{EC}-2$ were used. Valid data from EC-1 were obtained for $59 \%$ of the year (after quality control). Valid data from EC-2, which were restricted by power availability, were $32 \%$ of the year (after quality control). Data availability was the lowest in winter (38\% and $4 \%$ in winter, $71 \%$ and $6 \%$ in spring, $67 \%$ and $70 \%$ in summer, and $60 \%$ and $51 \%$ in fall for EC- 1 and EC-2, respectively). In this study, net fluxes of $\mathrm{CO}_{2}$ and $\mathrm{CH}_{4}$ toward the ecosystem surface are negative and net fluxes from the ecosystem surface to the atmosphere are positive. Therefore, negative NEE and $F_{\mathrm{m}}$ represent net $\mathrm{CO}_{2}$ and $\mathrm{CH}_{4}$ uptake, respectively.

\subsubsection{Gap filling of $\mathrm{CO}_{2}$ flux data}

For gaps longer than $2 \mathrm{~h}$ in $\mathrm{CO}_{2}$ fluxes, the $\mathrm{CO}_{2}$ flux (i.e. NEE) was modelled as the difference between $R_{\mathrm{e}}$ and GEP, i.e. $\mathrm{NEE}=R_{\mathrm{e}}-$ GEP. Nocturnal NEE values were $R_{\mathrm{e}}$ as there is no photosynthesis at night.

$R_{\mathrm{e}}$ was modelled based on soil temperature at the $5 \mathrm{~cm}$ depth $\left(T_{\mathrm{s}, 5 \mathrm{~cm}}\right)$ using a logistic fit (Neter et al., 1988):

$R_{\mathrm{e}}=\frac{1}{r_{1} r_{2}^{T_{\mathrm{s}, 5 \mathrm{~cm}}}+r_{3}}$.

A comparable logistic function was proposed and used by FLUXNET Canada (Barr et al., 2002; Kljun et al., 2006). In this study, we used this logistic model available in IDL (version 8.5.1, Exelis Visual Information Solutions, Boulder, Colorado). $r_{1}, r_{2}$, and $r_{3}$ are empirical parameters: $r_{1}$ controls the slope of exponential phase, $r_{2}$ determines where the transitional phase starts, and $r_{3}$ determines the height of plateau phase. For each day of the year, the parameters $r_{1}, r_{2}$, 
and $r_{3}$ for $R_{\mathrm{e}}$ were determined independently using a moving \pm 60 -day window centred on that day based on all measured nighttime data from 2014 to 2016 when friction velocity was higher than $0.08 \mathrm{~m} \mathrm{~s}^{-1}$. Lee (2016) determined the effect of using different window sizes $(60,90,120$, and full year) on the annual modelled and gap-filled $R_{\mathrm{e}}$ and showed that a moving window size of 120 days was least sensitive to errors while still allowing for seasonal changes. However, sensitivity of choosing different window sizes on gap-filled $R_{\mathrm{e}}$ was small, varying the annual value between 226 and $245 \mathrm{~g} \mathrm{CO}_{2}$ $\mathrm{C} \mathrm{m}^{-2} \mathrm{yr}^{-1}$.

GEP was first partitioned from measured daytime NEE using modelled $R_{\mathrm{e}}$. Any missing GEP data were then modelled using the photosynthetic light-response curves (Ögren and Evans, 1993) based on photosynthetic photon flux density (PPFD in $\mu \mathrm{mol} \mathrm{m}^{-2} \mathrm{~s}^{-1}$ ):

$\mathrm{GEP}=\frac{\mathrm{MQY} \cdot \mathrm{PPFD}+P_{\mathrm{M}}-\left(\left(\mathrm{MQY} \cdot \mathrm{PPFD}+P_{\mathrm{M}}\right)^{2}-4 \cdot C_{v} \cdot \mathrm{MQY} \cdot \mathrm{PPFD} \cdot P_{\mathrm{M}}\right)^{0.5}}{2 \cdot C_{v}}$.

Maximum photosynthetic rate at light saturation $\left(P_{\mathrm{M}}\right)$ and maximum quantum yield (MQY) are fitted parameters with GEP estimated as measured daytime NEE minus daytime $R_{\mathrm{e}}$ calculated using Eq. (1). Convexity $\left(C_{v}\right)$ was fixed at 0.7 (Farquhar et al., 1980). For each day of the year, the timevarying parameters MQY and $P_{\mathrm{M}}$ were determined independently using a moving \pm 45 -day window centred on that day using all data from 2014 to 2016 when friction velocity was higher than $0.08 \mathrm{~m} \mathrm{~s}^{-1}$. The sensitivity of window size on gap-filled GEP was small, resulting in annual value to vary between 385 and $415 \mathrm{~g} \mathrm{CO}_{2}-\mathrm{C} \mathrm{m}^{-2} \mathrm{yr}^{-1}$.

\subsubsection{Gap filling of $\mathrm{CH}_{4}$ flux data}

$\mathrm{CH}_{4}$ fluxes with quality flags 0 and 1 according to Foken et al. (2004) were plotted against all relevant variables including NEE, WTH, $\theta_{\mathrm{w}}, T_{\mathrm{a}}, T_{\mathrm{s}, 5 \mathrm{~cm}}, T_{\mathrm{s}, 10 \mathrm{~cm}}$, and $T_{\mathrm{s}, 50 \mathrm{~cm}}$. The highest correlation between a single variable and the $\mathrm{CH}_{4}$ flux was found for soil temperature using an exponential relationship (Fig. S3). Of the soil temperatures measured at three different depths, $T_{\mathrm{s}, 10 \mathrm{~cm}}$ explained the highest proportion of the variance in $\mathrm{CH}_{4}$ flux (Table $\mathrm{S} 1$ in the Supplement). Therefore, $T_{\mathrm{s}, 10 \mathrm{~cm}}$ was used to build an initial model and a logarithmic transformation of the $\mathrm{CH}_{4}$ fluxes was applied to remove the heteroscedasticity and permit the use of a linear regression model. Then the residual analysis was applied to explore whether the variance in the residual could be explained by other controls. The residual was defined as the ratio of the measured $\mathrm{CH}_{4}$ fluxes to the modelled $\mathrm{CH}_{4}$ fluxes from the initial model. Based on the residual analysis, the main contributor to the residual, WTH, explained $7 \%$ of the variance (Table S2). Additionally, there was a hysteresis relationship between $\mathrm{CH}_{4}$ flux and WTH (Fig. S4). In order to have a more robust gap-filling model, $T_{\mathrm{s}, 10 \mathrm{~cm}}$ and $\mathrm{WTH}$ were used to fill the gaps in $\mathrm{CH}_{4}$ fluxes. We used a combination of an exponentional temperature response function and a linear WTH function as follows:

$F_{\mathrm{m}}=(a \mathrm{WTH}+b) e^{c T_{\mathrm{s}, 10 \mathrm{~cm}}}$,

where $a, b$, and $c$ are time-varying empirical parameters. The three parameters were fitted separately for each day, using a moving window of \pm 105 days using all data from the study period when friction velocity was greater than $0.08 \mathrm{~m} \mathrm{~s}^{-1}$. Overall, $76 \%$ of the variance of the $\mathrm{CH}_{4}$ fluxes was explained by $T_{\mathrm{s}, 10 \mathrm{~cm}}$ and WTH. The combination of soil temperature and WTH has also been shown to explain a large proportion of the observed variances in $\mathrm{CH}_{4}$ fluxes in peatlands in other studies (Brown et al., 2014; Goodrich et al., 2015).

\subsubsection{Error estimates}

The uncertainty associated with annual estimates of NEE, GEP, $R_{\mathrm{e}}$, and $\mathrm{CH}_{4}$ fluxes resulting from gap filling and due to different window sizes was quantified as follows: first, in the annual dataset of half-hourly fluxes random gaps were inserted using Monte Carlo simulation (Griffis et al., 2003; Krishnan et al., 2006; Paul-Limoges et al., 2015); The maximum number of gaps were set to 40 and the maximum length was set to 10 days, resulting in total gaps of on average $28 \%$ of the year (and up to $40 \%$ of the year). The Monte Carlo simulation was run 500 times and the $95 \%$ confidence intervals were used to calculate the uncertainty of the annual sums.

Secondly, the uncertainty associated with choosing different window sizes for the derivation of the relationships in the gap filling (see Sect. 3.3.1 and 3.3.2) was estimated from a range of annual values obtained using window sizes of 30 , $45,60,75,90,120,150,180$, and 365 days for GEP, $R_{\mathrm{e}}$, and NEE; the same selections of window sizes with three additions $(210,240$, and 270 days) were applied for calculating the uncertainty of the annual $\mathrm{CH}_{4}$ budget. The overall uncertainty in the annual estimates of NEE, GEP, $R_{\mathrm{e}}$, and $\mathrm{CH}_{4}$ fluxes was then obtained by taking the square root of the sum of squares of the error from the gap filling (Monte Carlo simulation) and the uncertainty of the estimates due to different window sizes.

\subsection{Calculating $\mathrm{CO}_{2}$ eq.}

The combined effect of all long-lived greenhouse gases was compared for $\mathrm{CO}_{2}$ and $\mathrm{CH}_{4}$ by converting the molar fluxes of $\mathrm{CO}_{2}$ and $\mathrm{CH}_{4}$ into time-integrated radiative forcing (i.e. GWP) expressed on a mass basis in terms of $\mathrm{CO}_{2}$ equivalents $\left(\mathrm{g} \mathrm{CO}_{2}\right.$ eq. $\left.\mathrm{m}^{-2} \mathrm{~s}^{-1}\right)$ as follows:

$\mathrm{CO}_{2}$ eq. $(\mathrm{g})=m_{\mathrm{CO}_{2}} F_{\mathrm{c}}+\mathrm{GWP}_{\mathrm{CH}_{4}} m_{\mathrm{CH}_{4}} F_{\mathrm{m}}$,

where $\mathrm{GWP}_{\mathrm{CH}_{4}}$ is the mass-based GWP for the $\mathrm{CH}_{4}\left(\mathrm{~g} \mathrm{~g}^{-1}\right)$, $m_{\mathrm{CO}_{2}}$ is the molecular mass of $\mathrm{CO}_{2}\left(44.01 \mathrm{~g} \mathrm{~mol}^{-1}\right)$, and $m_{\mathrm{CH}_{4}}$ is the molecular mass of $\mathrm{CH}_{4}\left(16.04 \mathrm{~g} \mathrm{~mol}^{-1}\right)$. In this 
study, a 100 -year GWP of $\mathrm{CH}_{4}$ of 28 and a 20 -year GWP of $\mathrm{CH}_{4}$ of 84 were used (IPCC, 2014). $\mathrm{N}_{2} \mathrm{O}$ fluxes have been neglected in this study because previous chamber-based measurements during the growing season found no significant emissions or uptake of $\mathrm{N}_{2} \mathrm{O}$ in all study plots in the BBECA (Christen et al., 2016).

\section{Results and discussion}

\subsection{Weather}

During the study period (16 June 2015 to 15 June 2016), the site experienced an annual average $T_{\mathrm{a}}(2 \mathrm{~m}$ height $)$ of $11.3^{\circ} \mathrm{C}$. Mean monthly $T_{\mathrm{a}}$ ranged between 4.4 (January 2016) and $19.3{ }^{\circ} \mathrm{C}$ (July 2015). The study site received a total annual precipitation of $1062 \mathrm{~mm}$, of which $16 \%(174 \mathrm{~mm})$ fell during the warm half of the year (AprilSeptember) and $84 \%(888 \mathrm{~mm})$ during the cold half of the year (October-March) (Fig. 2). There was no lasting snow cover during the study year. However, the surface was frozen over 10 days in January 2016, with an ice thickness of up to $5 \mathrm{~cm}$.

Winds at this site were often influenced by a sea-land breeze circulation. Under sea-breeze situations, wind mainly came from the south ( $40 \%$ of all cases). Sometimes, however, the sea-land breeze blew from the west, primarily between 17:00 and 19:00 PST. The wind direction on average turned to the east during the nighttime (land breeze), and generally at night the winds were weaker.

\subsection{Surface conditions}

\subsubsection{Turbulent flux footprints}

Cumulative turbulent source areas were calculated using the analytical turbulent source area (turbulent footprint) model (Kormann and Meixner, 2001) following the procedure outlined in Christen et al. (2011). The $80 \%$ contour line (enclosing $80 \%$ of the cumulative probability for a unit source) was entirely inside the field in spring and summer. It reached beyond the ditches at the north side in fall and winter. Unstable conditions during daytime allowed for a more constrained footprint surrounding the tower. Stable conditions at night led to larger footprints, primarily from the east. The cumulative footprint for each of the four seasons for the EC1 overlaid on the satellite image of the site are documented in Fig. S1 (Supplement).

\subsubsection{Vegetation cover and water table changes}

Mosses and white beak sedge (the common name of Rhynchospora alba) started to grow in March and grasses grew up to a maximum of $0.3 \mathrm{~m}$ height in summer. In summer, vegetation covered almost the entire study area of the surface, including ponds (some with algae), so the surface was less

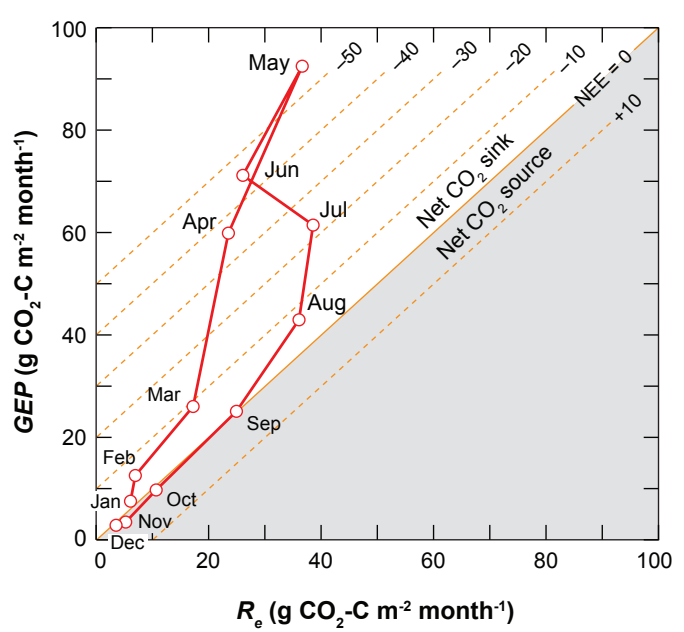

Figure 3. Monthly gap-filled $R_{\mathrm{e}}$ ( $x$ axis) drawn against GEP ( $y$ axis). The resulting NEE can be read off the diagonal lines. The thick 1:1 line shows carbon neutrality, while lines in the upper right are of increasingly negative NEE (uptake) and lines towards the lower right are positive NEE (net source).

patchy in summer compared to other seasons, when standing water ponds were intermixed with vegetation in fall, winter, and spring (Fig. S2).

Winter was the wettest season when WTH was mostly above the bare soil (reference surface). The highest water table position was $7.7 \mathrm{~cm}$ above the reference surface in December. In the dry season, the water table position dropped to $26.5 \mathrm{~cm}$ beneath the bog surface in August. The WTH decreased in spring, and dry hummocks could be seen from April to September. The water table started to rise above the surface after receiving the fall precipitation. The study site was flooded in winter during the study year.

\section{$4.3 \mathrm{CO}_{2}$ exchange}

\subsubsection{Annual, seasonal, and monthly NEE, $R_{\mathrm{e}}$, and GEP}

Overall, the study area was a $\mathrm{CO}_{2}$ sink in spring (MAM, $-1.10 \mathrm{~g} \mathrm{CO}_{2}-\mathrm{C} \mathrm{m}^{-2} \mathrm{day}^{-1}$ ) and in summer (JJA, $\left.-0.82 \mathrm{~g} \mathrm{CO}_{2}-\mathrm{C} \mathrm{m}^{-2} \mathrm{day}^{-1}\right)$. Net $\mathrm{CO}_{2}$ fluxes were near zero in fall ( $\mathrm{SON},+0.03 \mathrm{~g} \mathrm{CO}_{2}-\mathrm{C} \mathrm{m}^{-2} \mathrm{day}^{-1}$ ) and winter (DJF, $\left.-0.07 \mathrm{~g} \mathrm{CO}_{2}-\mathrm{C} \mathrm{m}^{-2} \mathrm{day}^{-1}\right)$. Over the entire year, the annual $\mathrm{CO}_{2}-\mathrm{C}$ budget (i.e. NEE) was $-179 \pm 26.2 \mathrm{~g} \mathrm{CO}_{2}$ $\mathrm{C} \mathrm{m}^{-2} \mathrm{yr}^{-1}$. Almost in each month of the calendar year, the site was a weak sink for $\mathrm{CO}_{2}$ except in October, November, and December (Fig. 3, Table 1). Monthly net fluxes of $\mathrm{CO}_{2}$ (NEE) ranged from $+1.77 \mathrm{~g} \mathrm{CO}_{2}-\mathrm{C} \mathrm{m}^{-2}$ month $^{-1}$ in November 2015 to $-56.20 \mathrm{~g} \mathrm{CO}_{2}-\mathrm{C} \mathrm{m}^{-2}$ month $^{-1}$ in May 2016.

The annual $R_{\mathrm{e}}$ and GEP during the study year were $236 \pm 16.4$ and $415 \pm 28.8 \mathrm{~g} \mathrm{CO}_{2}-\mathrm{C} \mathrm{m}^{-2} \mathrm{yr}^{-1}$, respectively. The relative changes in $R_{\mathrm{e}}$ and GEP were closely linked to the seasonality of the plant phenology. Based on GEP 
Table 1. Monthly EC-measured and gap-filled NEE ( $\mathrm{CO}_{2}$ fluxes), $\mathrm{CH}_{4}$ fluxes, $\mathrm{CO}_{2}$ eq. fluxes using 20-year $\mathrm{GWP}$, and $\mathrm{CO}_{2}$ eq. fluxes using 100 -year GWP at the study site during the study period.

\begin{tabular}{|c|c|c|c|c|c|c|}
\hline Month & $\begin{array}{l}R_{\mathrm{e}} \\
(\mathrm{g} \mathrm{CC}\end{array}$ & $\begin{array}{r}\text { GEP } \\
2-\mathrm{C} \mathrm{m}^{-2} \mathrm{mc} \\
\end{array}$ & th $\left.^{-1}\right)$ NEE & $\begin{array}{r}\mathrm{CH}_{4} \text { fluxes } \\
\left(\mathrm{mg} \mathrm{CH}_{4}-\mathrm{C} \mathrm{m}^{-2} \text { month }^{-1}\right)\end{array}$ & $\begin{array}{r}\text { 20-year } \mathrm{CO}_{2} \text { eq. fluxes } \\
\left(\mathrm{g} \mathrm{CO}_{2} \text { eq. } \mathrm{m}^{-2} \text { month }^{-1}\right)\end{array}$ & $\begin{array}{r}100 \text {-year } \mathrm{CO}_{2} \text { eq. fluxes } \\
\left(\mathrm{g} \mathrm{CO}_{2} \text { eq. } \mathrm{m}^{-2} \text { month }^{-1}\right)\end{array}$ \\
\hline January & 6.17 & 7.50 & -1.33 & 93 & 2.06 & -2.57 \\
\hline February & 6.94 & 12.46 & -5.52 & 224 & -10.82 & -17.09 \\
\hline March & 17.33 & 25.89 & -8.59 & 465 & -7.18 & -23.38 \\
\hline April & 23.52 & 59.73 & -36.21 & 1170 & -35.33 & -100.29 \\
\hline May & 36.46 & 92.63 & -56.20 & 1643 & -39.42 & -150.53 \\
\hline June & 26.13 & 71.10 & -44.97 & 2670 & 144.23 & -61.85 \\
\hline July & 38.53 & 61.47 & -22.94 & 4371 & 474.88 & 102.22 \\
\hline August & 36.15 & 42.97 & -6.82 & 3813 & 492.32 & 147.44 \\
\hline September & 24.84 & 25.08 & -0.21 & 1650 & 180.67 & 59.71 \\
\hline October & 10.76 & 9.58 & 1.18 & 930 & 77.23 & 28.62 \\
\hline November & 5.16 & 3.39 & 1.77 & 240 & 19.93 & 10.97 \\
\hline December & 3.63 & 2.79 & 0.87 & 155 & 10.13 & 5.50 \\
\hline \multirow[t]{2}{*}{ Study year } & \multicolumn{3}{|c|}{$\mathrm{gCO}_{2}-\mathrm{C} \mathrm{m}^{-2} \mathrm{yr}^{-1}$} & $\mathrm{~g} \mathrm{CH}_{4}-\mathrm{Cm}^{-2} \mathrm{yr}^{-1}$ & \multicolumn{2}{|c|}{$\mathrm{g} \mathrm{CO}_{2}$ eq. $\mathrm{m}^{-2} \mathrm{yr}^{-1}$} \\
\hline & $236 \pm 16.4$ & $415 \pm 28.8$ & $-179 \pm 26.2$ & $17 \pm 1$ & $1248 \pm 147.6$ & $-22 \pm 103.1$ \\
\hline
\end{tabular}

trends, we can divide the study period into three segments: "winter" (October-March), "early growing season" (April-June), and "late growing season" (JulySeptember). The rising temperature triggered growth in the early growing season $\left(\mathrm{GEP}=59.73 \mathrm{~g} \mathrm{CO}_{2}-\mathrm{C} \mathrm{m}^{-2}\right.$ month $\left.^{-1}\right)$, while the later growing season had limited growth $\left(\mathrm{GEP}=25.08 \mathrm{~g} \mathrm{CO}_{2}-\mathrm{C} \mathrm{m}^{-2}\right.$ month $\left.^{-1}\right)$. Winter had lowest productivity $\left(\mathrm{GEP}=7.58 \mathrm{~g} \mathrm{CO}_{2}-\mathrm{C} \mathrm{m}^{-2} \mathrm{month}^{-1}\right)$ (Table 1$)$. Compared to a large seasonal amplitude in monthly GEP, $R_{\mathrm{e}}$ showed less variability over the year. The highest rate of increase in the magnitude of NEE and the highest magnitude of NEE both occurred early in the growing season (Fig. 3). This was caused by the onset of $R_{\mathrm{e}}$ being delayed compared to GEP, resulting in the greatest imbalance between respiratory and assimilatory fluxes in May.

Table 2 compares annual NEE, $R_{\mathrm{e}}$, and GEP at the study site to FLUXNET sites over other land covers in the same region that experienced similar climate forcings, although from different years. An unmanaged grassland site $15 \mathrm{~km}$ to the west of the study area in the Fraser River delta (Westham Island, Delta, BC; Crawford et al., 2013) had about 1.3 times higher NEE than this rewetted area. Annual $R_{\mathrm{e}}$ and GEP values at this grassland site were higher than the study site by a factor of 5.2 and 3.5. A mature 55-year-old Douglas fir forest on Vancouver Island ( $200 \mathrm{~km} \mathrm{NW}$ of the study area; $\mathrm{Kr}-$ ishnan et al., 2009) showed an NEE of 1.8 times higher than the study area. The $R_{\mathrm{e}}$ and GEP were even higher by factors of 7.8 and 5.2, respectively. A young forest plantation (Buckley Bay, $150 \mathrm{~km} \mathrm{~W}$ of the study area; Krishnan et al., 2009), which was a weak C source, had $R_{\mathrm{e}}$ and GEP of 6- and 3 -fold higher than the study site, respectively. Compared to these other sites under similar climatic conditions, the rewetted area of the bog was not an ecosystem of high productivity but one with considerably limited $R_{\mathrm{e}}$ that permits more effi- cient $\mathrm{CO}_{2}$ sequestration (-NEE is $43 \%$ of GEP, as opposed to $15 \%$ for the unmanaged grassland site and mature forest).

The annual NEE in this study was more negative than in the majority of previously reported NEE values for undisturbed temperate peatlands, which were weak sinks, typically in the range of $-50 \mathrm{~g} \mathrm{CO}_{2}-\mathrm{C} \mathrm{m}^{-2} \mathrm{yr}^{-1}$ (Christensen et al., 2012; Humphreys et al., 2014; Peichl et al., 2014; McVeigh et al., 2014; Pelletier et al., 2015; Roulet et al., 2007). Values that are comparable to the current restored wetland were reported in five pristine temperate wetlands: $-248 \mathrm{~g} \mathrm{CO}_{2}$ $\mathrm{C} \mathrm{m}^{-2} \mathrm{yr}^{-1}$ (Lafleur et al., 2001), $-234 \mathrm{~g} \mathrm{CO}_{2}-\mathrm{C} \mathrm{m}^{-2} \mathrm{yr}^{-1}$ (Campbell et al., 2014), $-210 \mathrm{~g} \mathrm{CO}_{2}-\mathrm{C} \mathrm{m}^{-2} \mathrm{yr}^{-1}$ (Fortuniak et al., 2017), $-189 \mathrm{~g} \mathrm{CO}_{2}-\mathrm{C} \mathrm{m}^{-2} \mathrm{yr}^{-1}$ (Flanagan and Syed, 2011), and $-103 \mathrm{~g} \mathrm{CO}_{2}-\mathrm{C} \mathrm{m}^{-2} \mathrm{yr}^{-1}$ (Lund et al., 2010). The few datasets in the literature for NEE of restored wetlands showed a wide range of values. Some were $\mathrm{CO}_{2}$ sources, with NEE ranging from +103 to $+142 \mathrm{~g} \mathrm{CO}_{2}-\mathrm{C} \mathrm{m}^{-2} \mathrm{yr}^{-1}$ (Järveoja et al., 2016; Richards and Craft, 2015; Strack and Zuback, 2013). Other measurements, however, showed that restored wetlands were sinks, all of them stronger than in this study, with NEE values ranging from -446 to $-270 \mathrm{~g} \mathrm{CO}_{2}$ $\mathrm{C} \mathrm{m}^{-2} \mathrm{yr}^{-1}$ (Badiou et al., 2011; Hendriks et al., 2007; Herbst et al., 2013; Knox et al., 2015). In this study, values of $R_{\mathrm{e}}$ and GEP were lower than those found for a restored wetland at a comparable latitude in the central Netherlands with slightly lower annual temperature and precipitation (Hendriks et al., 2007). $R_{\mathrm{e}}$ and GEP in this study area were also lower than values for most pristine peatlands at comparable latitudes (Helfter et al., 2015; Levy and Gray, 2015). Comparably low $R_{\mathrm{e}}$ and GEP were reported from the Mer Bleue boreal raised bog (Lafleur et al., 2001; Moore, 2002) and from an Atlantic blanket bog (McVeigh et al., 2014; Sottocornola and Kiely, 2010), both of which had a lower mean annual temperature than Burns Bog. 
Table 2. Comparison of annual NEE, $R_{\mathrm{e}}$ and GEP, over different ecosystems (vegetation covers) in the Vancouver region using EC measurements. Sorted by magnitude of -NEE / GEP ratio.

\begin{tabular}{|c|c|c|c|c|c|}
\hline \multirow[t]{2}{*}{ Site } & \multirow[t]{2}{*}{ Land cover } & NEE & $R_{\mathrm{e}}$ & GEP & \multirow[t]{2}{*}{$-\mathrm{NEE} / \mathrm{GEP}$} \\
\hline & & \multicolumn{3}{|c|}{$\mathrm{g} \mathrm{CO}_{2}-\mathrm{C} \mathrm{m}^{-2} \mathrm{yr}^{-1}$} & \\
\hline $\begin{array}{l}\text { Burns Bog } \\
\text { (this study) } \\
\text { Delta, BC }\end{array}$ & Rewetted raised bog ecosystem & -179 & 236 & 415 & $43 \%$ \\
\hline $\begin{array}{l}\text { Westham Island } \\
\left(_{\text {CA-Wes })^{\mathrm{a}}}\right. \\
\text { Delta, BC }\end{array}$ & Unmanaged grassland & -222 & 1215 & 1438 & $15 \%$ \\
\hline $\begin{array}{l}\text { Campbell River } \\
(\mathrm{CA}-\mathrm{Ca} 1)^{\mathrm{a}} \\
\text { Vancouver Island }\end{array}$ & Douglas fir forest $(\sim 55$ years $)$ & $-328^{b}$ & $1830^{\mathrm{b}}$ & $2158^{b}$ & $15 \%$ \\
\hline $\begin{array}{l}\text { Buckley Bay } \\
(\mathrm{CA}-\mathrm{Ca} 3)^{\mathrm{a}} \\
\text { Vancouver Island }\end{array}$ & Douglas fir forest $(\sim 15$ years $)$ & $64^{\mathrm{b}}$ & $1487^{\mathrm{b}}$ & $1423^{b}$ & $-4 \%$ \\
\hline
\end{tabular}

${ }^{a}$ Site identifier in global FLUXNET database (http://fluxnet.ornl.gov). ${ }^{\mathrm{b}}$ Data from Krishnan et al. (2009) before fertilization.

It is important to estimate dissolved organic carbon (DOC) export to determine a more complete ecosystem $\mathrm{C}$ budget. DOC lost from restored and pristine peatlands have been found typically to range from 3.4 to $16.1 \mathrm{~g} \mathrm{C} \mathrm{m}^{-2} \mathrm{yr}^{-1}$ (Hendriks et al., 2007; Koehler et al., 2011; Roulet et al., 2007; Waddington et al., 2010), although Chu et al. (2014) reported a net DOC import for a marsh of $23 \pm 13 \mathrm{~g} \mathrm{C} \mathrm{m}^{-2} \mathrm{yr}^{-1}$. Estimation of DOC fluxes was based on regular (approximately monthly) water samples collected at five locations within the flux tower footprint. Water samples were analyzed for DOC concentrations using a TOC analyzer (model TOC-VCSH, Shimadzu Scientific, Kyoto, Japan). Lateral water export was estimated as the residual of the water balance. D'Acunha et al. (2016) estimated DOC export for the current study area for January-December 2016 to be $22.4 \mathrm{~g} \mathrm{C} \mathrm{m}^{-2} \mathrm{yr}^{-1}$ (15\% of annual NEE).

\subsubsection{Diurnal variability in $\mathrm{CO}_{2}$ fluxes}

The seasonally changing diurnal course of gap-filled NEE with isopleths over time of day and year is shown in Fig. 4. The daily maximum in GEP changed with season resulting in the high magnitude of NEE during midday between May and July $\left(\sim-3.5 \mu \mathrm{mol} \mathrm{m}^{-2} \mathrm{~s}^{-1}\right)$ with the highest magnitude of NEE occurring in May. Nighttime NEE, i.e. $R_{\mathrm{e}}$, showed relatively small variation with season and on average was $\leq 1 \mu \mathrm{mol} \mathrm{m}{ }^{-2} \mathrm{~s}^{-1}$ for most of the study period. The rapid decrease in monthly $R_{\mathrm{e}}$ from May to June (Table 1) was caused by low $R_{\mathrm{e}}$ in early morning or at nightfall in June.

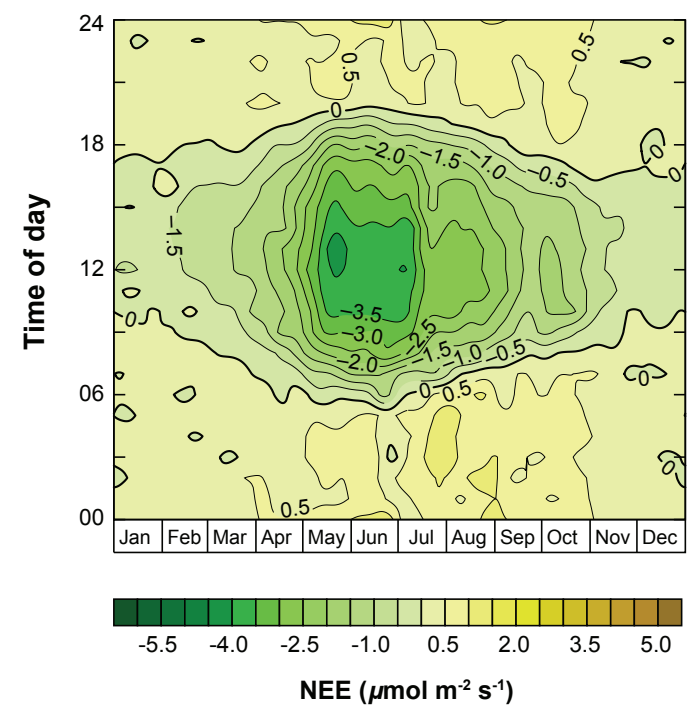

Figure 4. Isopleths of gap-filled NEE (net $\mathrm{CO}_{2}$ fluxes) from the EC-1 system plotted as a composite in the study year. The graph uses a Gaussian filter of $\sigma=45$ days (which conserves total NEE) to graphically smooth horizontal variations.

\subsubsection{Ecosystem respiration}

Figure 5 shows the relationship between nighttime $R_{\mathrm{e}}$ and $T_{\mathrm{S}, 5 \mathrm{~cm}}$ using the data for the entire study period. $R_{\mathrm{e}}$ increased with increasing $T_{\mathrm{s}, 5 \mathrm{~cm}}$ as expected and annually followed a logistic curve rather than an exponential relationship. $R_{\mathrm{e}}$ response curves were also calculated every 2 months (Fig. S5). $R_{\mathrm{e}}$ showed different curves depending on season. In winter, $R_{\mathrm{e}}$ varied little with $T_{\mathrm{s}, 5 \mathrm{~cm}}$ and was close to zero. From 


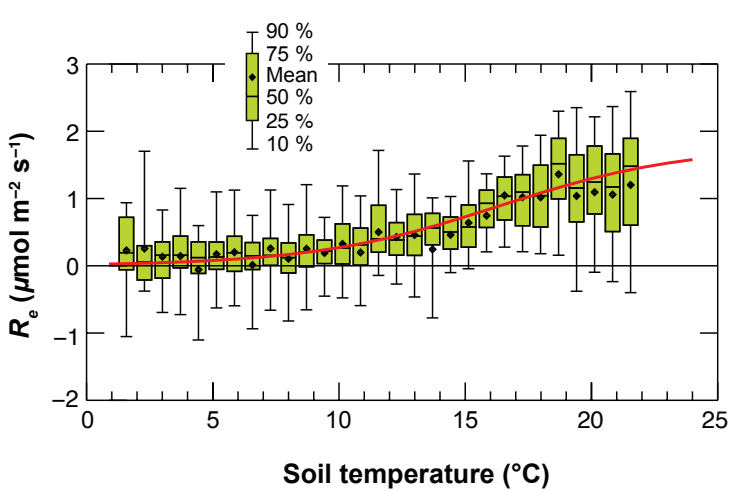

Figure 5. Relationship between $R_{\mathrm{e}}$ (nighttime $30 \mathrm{~min} \mathrm{CO}_{2}$ flux measurements) and $T_{\mathrm{s}, 5 \mathrm{~cm}}$ during the entire study period. The $u_{*}$ threshold was $0.08 \mathrm{~m} \mathrm{~s}^{-1}$. The fitted curve is a logistic relationship following Eq. (1). $T_{\mathrm{s}, 5 \mathrm{~cm}}$ was binned for 32 classes from minimum of $T_{\mathrm{s}, 5 \mathrm{~cm}}$ to maximum of $T_{\mathrm{s}, 5 \mathrm{~cm}}$. See Fig. S5 for seasonal differences. Negative $R_{\mathrm{e}}$ values were caused by measurement uncertainties.

February to May, the relationship became closer to logistic. In June and July, due to general warm condition $\left(>15^{\circ} \mathrm{C}\right)$, $R_{\mathrm{e}}$ remained nearly constant at $\sim 1 \mu \mathrm{mol} \mathrm{m}{ }^{-2} \mathrm{~s}^{-1}$ (the fitted curve stayed in the plateau phase). The study area had the highest $R_{\mathrm{e}}$ in these 2 months. In fall, $R_{\mathrm{e}}$ curves were closer to an exponential relationship, which could be due in part to leaf senescence (Shurpali et al., 2008). Decomposition of dead plant organic matter on the soil surface may have caused a higher $R_{\mathrm{e}}$ in fall compared to spring and winter at the same $T_{\mathrm{s}, 5 \mathrm{~cm}}$. Another factor could be the WTH, which in fall was not high enough to suppress $R_{\mathrm{e}}$ as it did in winter (Juszczak et al., 2013). The differences between March and September $R_{\mathrm{e}}$ at the same $T_{\mathrm{s}, 5 \mathrm{~cm}}$ were up to $0.4 \mu \mathrm{mol} \mathrm{m} \mathrm{m}^{-2} \mathrm{~s}^{-1}$.

Two other controls on $R_{\mathrm{e}}$ explored were air temperature $\left(T_{\mathrm{a}}\right)$ and WTH. The role of WTH was described above and $T_{\mathrm{a}}$ had a similar impact on $R_{\mathrm{e}}$ as $T_{\mathrm{s}, 5 \mathrm{~cm}}$ when $T_{\mathrm{a}}<16^{\circ} \mathrm{C}$, but for warmer temperatures $T_{\mathrm{a}}$ did not correlate with $R_{\mathrm{e}}$. The explanation for this is that heterotrophic component of $R_{\mathrm{e}}$ depends on $T_{\mathrm{S}}$, not the rapidly changing $T_{\mathrm{a}}$ (Davidson et al., 2002; Edwards, 1975; Lloyd and Taylor, 1994).

It is widely reported that in most terrestrial ecosystems, the activity of soil microbes is also governed by soil moisture status, having little activity when the soil is excessively dry or excessively wet. Accordingly, and like other wetlands, $R_{\mathrm{e}}$ was small when the water table was above the surface because this situation suppressed aerobic decomposition of peat (Rochefort et al., 2002; Weltzin et al., 2000). When the water table was below surface, $R_{\mathrm{e}}$ increased to near $1 \mu \mathrm{mol} \mathrm{m}{ }^{-2} \mathrm{~s}^{-1}$ and became stable no matter how low the water table position was. This relationship was also found in many other peatlands (Bridgham et al., 2006; Ellis et al., 2009; Strack et al., 2006). There was no obvious relationship between $\theta_{\mathrm{w}}$ (integrated from 0 to $30 \mathrm{~cm}$ depth) and $R_{\mathrm{e}} . R_{\mathrm{e}}$

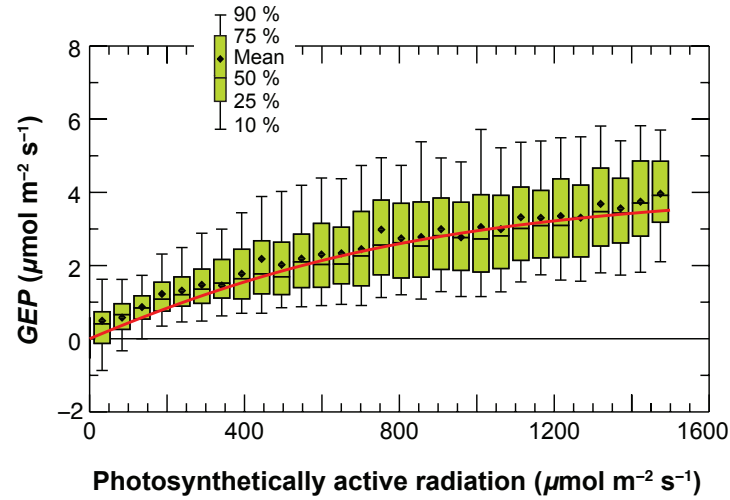

Figure 6. Annual light-response curve determined from the daytime 30 min NEE measurements and Eq. (1), i.e. GEP $=R_{\mathrm{e}}+-\mathrm{NEE}$. The curves are the best fit of the Eq. (2). PPFD was binned for 30 classes from 0 to $1500 \mu \mathrm{mol} \mathrm{m}^{-2} \mathrm{~s}^{-1}$. Annual MQY was $4.00 \mathrm{mmol} \mathrm{C} \mathrm{mol}^{-1}$ photons, $P_{\mathrm{M}}$ was $4.68 \mu \mathrm{mol} \mathrm{m}^{-2} \mathrm{~s}^{-1}$, and $C_{v}$ was 0.7 (fixed).

slightly decreased from 1.0 to $0.6 \mu \mathrm{mol} \mathrm{m}^{-2} \mathrm{~s}^{-1}$ when $\theta_{\mathrm{w}}$ increased from 84 to $88 \%$. Other than this range, $\theta_{\mathrm{w}}$ had no more impact on $R_{\mathrm{e}}$.

\subsubsection{Gross ecosystem productivity}

Figure 6 shows the average light-response curve, with half-hourly GEP as a function of PPFD. Due to different phenology over the year and the changes in solar altitude, light-response curves were also calculated every 2 months (Fig. S6). GEP reached a maximum in May with $92.63 \mathrm{~g} \mathrm{CO}_{2}-\mathrm{C} \mathrm{m}^{-2}$ month $^{-1}$ and a minimum of $2.79 \mathrm{~g} \mathrm{CO}_{2}-\mathrm{C} \mathrm{m}^{-2}$ month $^{-1}$ in December (Fig. 3, Table 1). GEP at light saturation reached roughly $5.09 \mu_{\mathrm{mol} \mathrm{m}}^{-2} \mathrm{~s}^{-1}$ in summer and remained below $2.49 \mu \mathrm{mol} \mathrm{m}^{-2} \mathrm{~s}^{-1}$ in winter due to reduced leaf area, flooding, and lower temperatures. From March to May, GEP increased much more rapidly than $R_{\mathrm{e}}$. In fall, GEP decreased faster than $R_{\mathrm{e}}$. The magnitude of $R_{\mathrm{e}}$ already was close to GEP in the late August to make the study area become $\mathrm{CO}_{2}$ neutral in late summer.

Other possible controls on GEP explored were WTH and $T_{\mathrm{a}}$. We found that WTH was not a control on GEP $\left(R^{2}=\right.$ 0.08 ) in the current study as the study area remained fairly wet throughout the year. Furthermore, the effect of $T_{\mathrm{a}}$ on GEP was less and limited to a smaller temperature range compared to $T_{\mathrm{s}}$.

\section{4 $\mathrm{CH}_{4}$ exchange}

\subsubsection{Annual and seasonal $\mathrm{CH}_{4}$ budgets}

Overall, the study area was a source of $\mathrm{CH}_{4}$ in each of the 12 months (Table 1). The annual $\mathrm{CH}_{4}-\mathrm{C}$ budget was $17 \pm 1.0 \mathrm{~g} \mathrm{CH}_{4}-\mathrm{C} \mathrm{m}^{-2} \mathrm{yr}^{-1}$. $\mathrm{CH}_{4}$ emissions were close to zero in winter $\left(5.2 \mathrm{mg} \mathrm{CH}_{4}-\mathrm{C} \mathrm{m}^{-2} \mathrm{day}^{-1}\right)$. Seasonally, it 
was a weaker $\mathrm{CH}_{4}$ source in fall $\left(31.3 \mathrm{mg} \mathrm{CH}_{4}-\mathrm{C} \mathrm{m}^{-2}\right.$ day $^{-1}$ ) and spring $\left(36.4 \mathrm{mg} \mathrm{CH}_{4}-\mathrm{C} \mathrm{m}^{-2} \mathrm{day}^{-1}\right)$ and then became a much larger source in summer $\left(126.0 \mathrm{mg} \mathrm{CH}_{4}\right.$ $\mathrm{C} \mathrm{m}^{-2}$ day $^{-1}$ ). Monthly emissions of $\mathrm{CH}_{4}$ ranged from 93 (January) to 4371 (July) $\mathrm{mg} \mathrm{CH}_{4}-\mathrm{C} \mathrm{m}^{-2}$ month $^{-1}$. The rising $T_{\mathrm{a}}$ did not trigger $\mathrm{CH}_{4}$ production immediately, and $\mathrm{CH}_{4}$ fluxes remained low in April and May. But once the subsurface and water became warm enough, $\mathrm{CH}_{4}$ emissions increased from to 1.4 to $2.7 \mathrm{~g} \mathrm{CH}_{4}-\mathrm{C} \mathrm{m}^{-2}$ month $^{-1}$ in June (Table 1). $\mathrm{CH}_{4}$ emissions reached the peak in July $\left(4.4 \mathrm{~g} \mathrm{CH}_{4}-\mathrm{C} \mathrm{m}^{-2}\right.$ month $\left.^{-1}\right)$ and held similar magnitude ( $3.8 \mathrm{~g} \mathrm{CH}_{4}-\mathrm{C} \mathrm{m}^{-2}$ month $^{-1}$ ) in August even though the $T_{\mathrm{a}}$ had dropped. Although it has been suggested that in some peatlands, WTH acts as a main control on $\mathrm{CH}_{4}$ fluxes (Drösler et al., 2008; Knorr et al., 2009; Romanowicz et al., 1995; Roulet et al., 1993; Windsor et al., 1992), it has also been found that $\mathrm{CH}_{4}$ emissions from wet soils (where the water table fluctuates within a small range near the surface) are highly dependent on $T_{\mathrm{S}}$ because the oxidation in a shallow top soil is negligible (Jackowicz-Korczynski et al., 2010; Long et al., 2010; Olson et al., 2013; Rinne et al., 2007; Song et al., 2009). In our study, $\mathrm{CH}_{4}$ emissions in the summer months were relative high even when the water table dropped to around $20 \mathrm{~cm}$ below the surface, likely because the peat maintained anaerobic conditions above the water table (as discussed in Hendriks et al., 2007). In addition, one needs to consider the transport pathways for $\mathrm{CH}_{4}$ which may help explain the higher $\mathrm{CH}_{4}$ fluxes in summer. First, the presence of sedges created an effective additional diffusion pathway for $\mathrm{CH}_{4}$ through the plants' aerenchyma (Herbst et al., 2011; Treat et al., 2007). Second, a high water table, especially when it rises above the soil surface, increases the diffusion resistance to $\mathrm{CH}_{4}$ transport (Brown et al., 2014; Walter and Heimann, 2000).

The annual $\mathrm{CH}_{4}$ flux in this study area was lower than $\mathrm{CH}_{4}$ fluxes reported for other restored wetlands (Anderson et al., 2016; Hendriks et al., 2007; Knox et al., 2015; Mitsch et al., 2010). Despite the study area being flooded for most of the study year, $\mathrm{CH}_{4}$ emissions were closer to fluxes measured over drained peatlands (Kroon et al., 2010; SchrierUijl et al., 2010). Only Herbst et al. (2013) reported an annual $\mathrm{CH}_{4}$ flux from a restored wetland in Denmark that was lower than in this study ( 9 to $13 \mathrm{~g} \mathrm{CH}_{4}-\mathrm{C} \mathrm{m}^{-2} \mathrm{yr}^{-1}$ ). Our annual $\mathrm{CH}_{4}$ flux at $17 \pm 1.0 \mathrm{~g} \mathrm{CH}_{4}-\mathrm{C} \mathrm{m}^{-2} \mathrm{yr}^{-1}$ was comparable to an average natural temperate wetland $\mathrm{CH}_{4}$ flux, which is typically around $15 \mathrm{~g} \mathrm{CH}_{4}-\mathrm{C} \mathrm{m}^{-2} \mathrm{yr}^{-1}$ (Abdalla et al., 2016; Fortuniak et al., 2017; Nicolini et al., 2013; Turetsky et al., 2014). The $\mathrm{CH}_{4}$ fluxes from a number of temperate and tropical pristine wetlands exceeded the $\mathrm{CH}_{4}$ fluxes reported in this study, including emissions from marshes in the southwestern US $\left(130 \mathrm{~g} \mathrm{CH}_{4}-\mathrm{C} \mathrm{m}^{-2} \mathrm{yr}^{-1}\right.$; Whiting and Chanton, 2001), tropical wetlands in Costa Rica (82 $\mathrm{g} \mathrm{CH}_{4}-\mathrm{C} \mathrm{m}^{-2} \mathrm{yr}^{-1}$; Nahlik and Mitsch, 2010), marshes in the midwestern US $\left(50 \mathrm{~g} \mathrm{CH}_{4}-\mathrm{C} \mathrm{m}^{-2} \mathrm{yr}^{-1}\right.$, Koh et al., 2009), all three studies based on chamber measurements, and

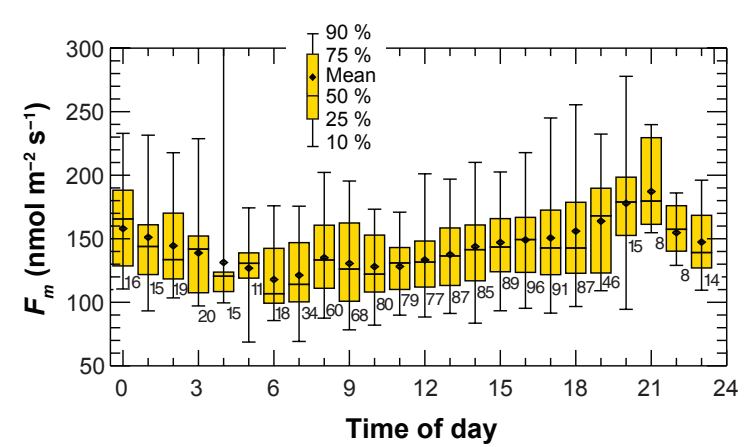

Figure 7. The ensemble-averaged diurnal course of measured $\mathrm{CH}_{4}$ fluxes from the EC-2 system in summer.

an ombrotrophic bog in New Zealand $\left(29\right.$ and $21 \mathrm{~g} \mathrm{CH}_{4}-$ $\mathrm{C} \mathrm{m}^{-2} \mathrm{yr}^{-1}$ based on EC measurements; Goodrich et al., 2015).

\subsubsection{Diurnal variability in $\mathrm{CH}_{4}$ fluxes}

The ensemble-averaged diurnal courses of the $\mathrm{CH}_{4}$ fluxes measured by the EC-2 system are shown in Fig. 7 during the summer months due to the lack of missing wintertime data caused by power restriction. Surprisingly, there was only a small diurnal variation observed for $\mathrm{CH}_{4}$ fluxes in the summer months, while larger diurnal variations have been found in other studies (Juutinen et al., 2004; Long et al., 2010; Sun et al., 2013; Wang and Han, 2005). In the current study area, with changes in WTH and vegetation growth occurring during the year, there were likely several processes affecting $\mathrm{CH}_{4}$ transport, which masked the diurnal pattern of $\mathrm{CH}_{4}$ fluxes. Furthermore, $T_{\mathrm{S}, 5 \mathrm{~cm}}$ appeared to be the main environmental control on $\mathrm{CH}_{4}$ fluxes in this study but did not have as strong effect on $\mathrm{CH}_{4}$ emissions as found in previous studies. Thus $\mathrm{CH}_{4}$ was continuously emitted at a similar rate during daytime and nighttime. From January to March and October to December, the winter half-year, the study site had constant $\mathrm{CH}_{4}$ emissions of less than $50 \mathrm{nmol} \mathrm{m}^{-2} \mathrm{~s}^{-1}$, and almost no diurnal variation was observed. July had the greatest $\mathrm{CH}_{4}$ emissions, and the highest magnitude $\left(>150 \mathrm{nmol} \mathrm{m}^{-2} \mathrm{~s}^{-1}\right)$ appeared in the evening (15:00 to 21:00). This corresponded to the lagged effect of soil temperature and may be partly due to convective turbulent mixing caused by cooling during the evening (Godwin et al., 2013).

\section{$4.5 \mathrm{CO}_{2}$ eq. balance}

Figure $8 \mathrm{a}$ and $\mathrm{b}$ show $\mathrm{CO}_{2}$ and $\mathrm{CH}_{4}$ fluxes expressed in terms of $\mathrm{CO}_{2}$ eq. using 100- and 20-year GWPs, respectively. Considering fluxes of both GHGs together, this rewetted area was annually near to $\mathrm{CO}_{2}$ eq. neutral at 100 -year scale with a net uptake by $\mathrm{CO}_{2}\left(-656 \mathrm{gCO}_{2}\right.$ eq. $\left.\mathrm{m}^{-2} \mathrm{yr}^{-1}\right)$ balanced by $\mathrm{CH}_{4}$ emissions $\left(634 \mathrm{~g} \mathrm{CO}_{2}\right.$ eq. $\left.\mathrm{m}^{-2} \mathrm{yr}^{-1}\right)$. On a shorter time horizon of 20 years, the study area repre- 


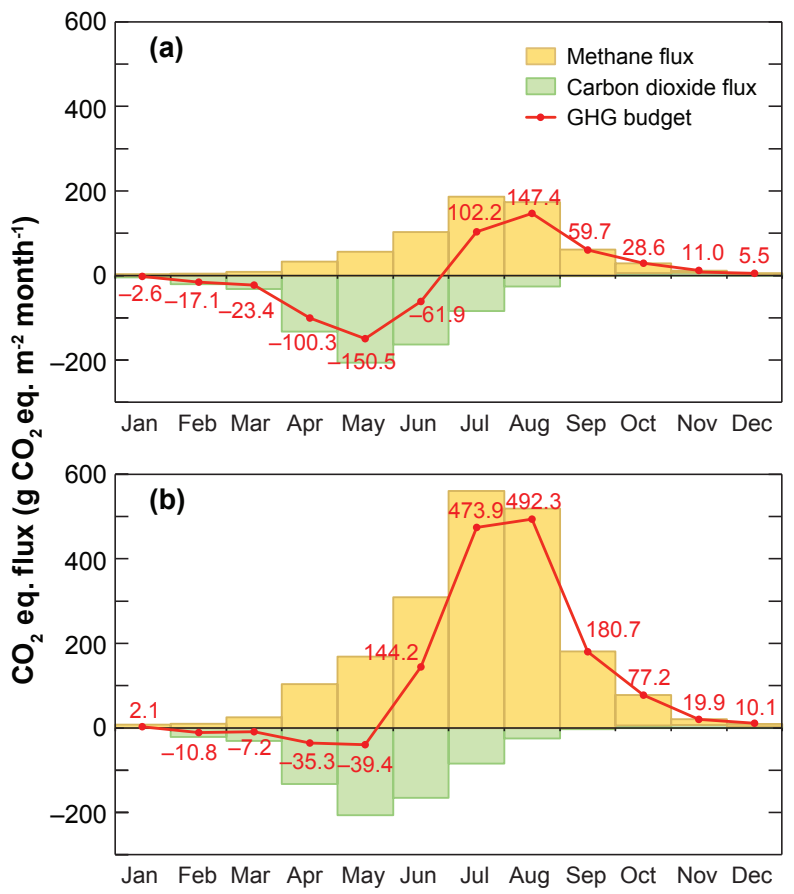

Figure 8. EC-measured monthly $\mathrm{CO}_{2}, \mathrm{CH}_{4}$, and net GHGs fluxes shown as $\mathrm{CO}_{2}$ eq. totals by using (a) 100-year and (b) 20-year GWPs. Missing data were gap-filled.

sented a significant $\mathrm{C}$ source in $\mathrm{CO}_{2}$ eq. terms as the net uptake of $\mathrm{CO}_{2}\left(-656 \mathrm{~g} \mathrm{CO}_{2}\right.$ eq. $\left.\mathrm{m}^{-2} \mathrm{yr}^{-1}\right)$ was one-third that of $\mathrm{CH}_{4}$ emissions ( $1904 \mathrm{~g} \mathrm{CO}_{2}$ eq. $\mathrm{m}^{-2} \mathrm{yr}^{-1}$ ). In late spring and early summer, the early onset of $\mathrm{CO}_{2}$ sequestration in May and the time lag in $\mathrm{CH}_{4}$ fluxes combined to represent a negative net GHG forcing, no matter which GWP time horizon was considered. The quick drop in $\mathrm{CO}_{2}$ sequestration in August and September allowed the highest net GHG forcing to be observed at both time horizons in late summer. In short, the critical time period for both, $\mathrm{CO}_{2}$ and $\mathrm{CH}_{4}$ fluxes in terms of $\mathrm{CO}_{2}$ eq., was the growing season when magnitude of fluxes changed differently across the growing season. The results show that measurements made during a part of the growing season are not necessarily representative for the entire growing season or the year; a short-term campaign can be a good way to identify important site processes but the determination of the annual budget requires reliable annual measurements.

Using GWP to classify a study area as a net GHG source or sink is useful; however, the appropriateness of this method in computing the actual radiative forcing has been questioned and alternative models have been proposed (Frolking and Roulet, 2007; Fuglestvedt et al., 2000; Neubauer and Megonigal, 2015; Petrescu et al., 2015; Smith and Wigley, 2000).

\section{Conclusions}

The study area, a rewetted plot in the BBECA undergoing ecological restoration, was a net $\mathrm{CO}_{2}$ sink over the study period $\left(-179 \mathrm{~g} \pm 26.2 \mathrm{CO}_{2}-\mathrm{C} \mathrm{m}^{-2} \mathrm{yr}^{-1}\right)$. The study area was not a highly productive ecosystem (annual $\mathrm{GEP}=415 \pm 28.8 \mathrm{~g} \mathrm{CO}_{2}-\mathrm{C} \mathrm{m}^{-2} \mathrm{yr}^{-1}$ ) but exhibited low $R_{\mathrm{e}}$ (annual $R_{\mathrm{e}}=236 \pm 16.4 \mathrm{~g} \mathrm{CO}_{2}-\mathrm{C} \mathrm{m}^{-2} \mathrm{yr}^{-1}$ ), likely due to oxygen limitations. The annual $\mathrm{CO}_{2}$ fluxes reported here from a restored and rewetted peatland are comparable with data reported from pristine temperate peatlands in temperate mid latitudes (Campbell et al., 2014; Flanagan and Syed, 2011; Fortuniak et al., 2017; Lund et al., 2010). The study area sequestered less $\mathrm{CO}_{2}$ than the few other restored wetlands reported in the literature (Badiou et al., 2011; Hendriks et al., 2007; Herbst et al., 2013; Knox et al., 2015). The major controls on $\mathrm{CO}_{2}$ fluxes were PAR irradiance and $T_{\mathrm{S}, 5 \mathrm{~cm}}$. The magnitude of PAR strongly controlled GEP, and the $T_{\mathrm{s}, 5 \mathrm{~cm}}$ regulated $R_{\mathrm{e}}$. WTH also had influence on $R_{\mathrm{e}}$, especially when the ecosystem was flooded.

The annual $\mathrm{CH}_{4}$ emissions were $17 \pm 1.0 \mathrm{~g} \mathrm{CH}_{4}-$ $\mathrm{C} \mathrm{m}^{-2} \mathrm{yr}^{-1}$, which is lower than values reported for other restored wetlands (Anderson et al., 2016; Hendriks et al., 2007; Knox et al., 2015; Mitsch et al., 2010). $\mathrm{CH}_{4}$ emissions in the summer were 60 times stronger than in the winter. The ditch blocking resulted in anaerobic conditions with the water table being within $30 \mathrm{~cm}$ of the surface throughout the year. Effects of changing WTH on $\mathrm{CH}_{4}$ fluxes at the study area were not clearly apparent. $T_{\mathrm{s}, 10 \mathrm{~cm}}$ and WTH explained $\mathrm{CH}_{4}$ fluxes best $\left(R^{2}=0.76\right)$.

In terms of the $\mathrm{C}$ balance (excluding DOC fluxes), our results suggest that our study area in BBECA was a net C sink $\left(-163 \pm 26.2 \mathrm{~g} \mathrm{C} \mathrm{m}^{-2} \mathrm{yr}^{-1}\right)$ during the eighth year following rewetting. Combining $\mathrm{CO}_{2}, \mathrm{CH}_{4}$, and DOC fluxes resulted in a net $\mathrm{C}$ balance of $-141 \pm 26.2 \mathrm{~g} \mathrm{C} \mathrm{m}^{-2} \mathrm{yr}^{-1}$. These results are consistent with those of several disturbed peatlands that have become a net annual $\mathrm{C}$ sink after restoration by rewetting (Karki et al., 2016; Schrier-Uijl et al., 2014; Wilson et al., 2013). In terms of net climate forcing of the system related to $\mathrm{CO}_{2}$ and $\mathrm{CH}_{4}$ fluxes expressed by GWPs, our results show that the ecosystem was almost $\mathrm{CO}_{2}$ eq. neutral $\left(\mathrm{CO}_{2}\right.$ eq. $(\mathrm{g})=-22 \pm 103.1 \mathrm{~g} \mathrm{CO}_{2}$ eq. $\left.\mathrm{m}^{-2} \mathrm{yr}^{-1}\right)$ over a 100 -year time horizon.

Data availability. Data from this study/site are available through AMERIFLUX (https://ameriflux.lbl.gov). The site ID is CA-DBB.

The Supplement related to this article is available online
at https://doi.org/10.5194/bg-14-2799-2017-supplement.

Competing interests. The authors declare that they have no conflict of interest. 
Acknowledgements. This research was primarily funded through research contracts between Metro Vancouver and UBC (PI: Christen). Selected equipment was supported by the Canada Foundation for Innovation (Christen, Johnson) and NSERC RTI (Christen). Financial support through scholarships and training were provided by UBC Faculty of Graduate and Postdoctoral Studies and UBC Geography. We appreciate the substantial technical and logistical support by Joe Soluri (Metro Vancouver) in operating the site and scientific contributions and data provided by C. Reynolds (Metro Vancouver) and S. Howie (Delta, BC).

Edited by: A. V. Eliseev

Reviewed by: D. Campbell and one anonymous referee

\section{References}

Abdalla, M., Hastings, A., Truu, J., Espenberg, M., Mander, Ü., and Smith, P.: Emissions of methane from northern peatlands: a review of management impacts and implications for future management options, Ecol. Evol., 6, 7080-7102, 2016.

Anderson, F. E., Bergamaschi, B., Sturtevant, C., Knox, S., Hastings, L., Windham-Myers, L., Detto, M., Hestir, E. L., Drexler, J., Miller, R. L., Matthes, J. H., Verfaillie, J., Baldocchi, D., Snyder, R. L., and Fujii, R.: Variation of energy and carbon fluxes from a restored temperate freshwater wetland and implications for carbon market verification protocols, J. Geophys. Res.-Biogeo., 121, 777-795, 2016

Aurela, M., Laurila, T., and Tuovinen, J.-P.: Seasonal $\mathrm{CO}_{2}$ balances of a subarctic mire, J. Geophys. Res.-Atmos., 106, 1623-1637, https://doi.org/10.1029/2000JD900481, 2001.

Badiou, P., McDougal, R., Pennock, D., and Clark, B.: Greenhouse gas emissions and carbon sequestration potential in restored wetlands of the Canadian prairie pothole region, Wetl. Ecol. Manag., 19, 237-256, 2011.

Barr, A. G., Griffis, T. J., Black, T. A., Lee, X., Staebler, R. M., Fuentes, J. D., Chen, Z., and Morgenstern, K.: Comparing the carbon budgets of boreal and temperate deciduous forest stands, Can. J. Forest Res., 32, 813-822, 2002.

Bergamaschi, P., Frankenberg, C., Meirink, J. F., Krol, M., Dentener, F., Wagner, T., Platt, U., Kaplan, J. O., Körner, S., Heimann, M., Dlugokencky, E. J., and Goede, A.: Satellite chartography of atmospheric methane from SCIAMACHY on board ENVISAT: 2. Evaluation based on inverse model simulations, J. Geophys. Res.-Atmos., 112, D2304, https://doi.org/10.1029/2006JD007268, 2007.

Bloom, A. A., Palmer, P. I., Fraser, A., Reay, D. S., and Frankenberg, C.: Large-Scale Controls of Methanogenesis Inferred from Methane and Gravity Spaceborne Data, Science, 327, 322-325, https://doi.org/10.1126/science.1175176, 2010.

Bridgham, S., Megonigal, J. P., Keller, J., Bliss, N., and Trettin, C.: The carbon balance of North American wetlands, Wetlands, 26, 889-916, 2006.

Brown, M. G., Humphreys, E. R., Moore, T. R., Roulet, N. T., and Lafleur, P. M.: Evidence for a nonmonotonic relationship between ecosystem-scale peatland methane emissions and water table depth, J. Geophys. Res.-Biogeo., 119, 826-835, 2014.

Campbell, D. I., Smith, J., Goodrich, J. P., Wall, A. M., and Schipper, L. A.: Year-round growing conditions explains large $\mathrm{CO}_{2}$ sink strength in a New Zealand raised peat bog, Agr. Forest Meteorol., 192-193, 59-68, 2014.

Chestnutt, C.: For peat's sake: A water balance study and comparison of the eddy covariance technique and semi-empirical calculation to determine summer evapotranspiration in Burns Bog, British Columbia, BSc, The University of Edinburgh, The University of British Columbia, 2015.

Christen, A., Coops, N. C., Crawford, B. R., Kellett, R., Liss, K. N., Olchovski, I., Tooke, T. R., van der Laan, M., and Voogt, J. A.: Validation of modeled carbon-dioxide emissions from an urban neighborhood with direct eddy-covariance measurements, Atmos. Environ., 45, 6057-6069, 2011.

Christen, A., Jassal, R. S., Black, T. A., Grant, N. J., Hawthorne, I., Johnson, M. S., Lee, S. C., and Merkens, M.: Summertime greenhouse gas fluxes from an urban bog undergoing restoration through rewetting, Mires and Peat, 18, 1-24, 2016.

Christensen, T. R., Jackowicz-Korczyński, M., Aurela, M., Crill, P., Heliasz, M., Mastepanov, M., and Friborg, T.: Monitoring the Multi-Year Carbon Balance of a Subarctic Palsa Mire with Micrometeorological Techniques, AMBIO, 41, 207-217, 2012.

Chu, H., Chen, J., Gottgens, J. F., Ouyang, Z., John, R., Czajkowski, K., and Becker, R.: Net ecosystem methane and carbon dioxide exchanges in a Lake Erie coastal marsh and a nearby cropland, J. Geophys. Res.-Biogeo., 119, 722-740, 2014.

Ciais, P., Sabine, C., Bala, G., Bopp, L., Brovkin, V., Canadell, J., Chhabra, A., DeFries, R., Galloway, J., Heimann, M., Jones, C., Le Quéré, C., Myneni, R. B., Piao, S., and Thornton, P.: Carbon and Other Biogeochemical Cycles, in: Climate Change 2013: The Physical Science Basis. Contribution of Working Group I to the Fifth Assessment Report of the Intergovernmental Panel on Climate Change, edited by: Stocker, T. F., Qin, D., Plattner, G.-K., Tignor, M., Allen, S. K., Boschung, J., Nauels, A., Xia, Y., Bex, V., and Midgley, P. M., Cambridge University Press, Cambridge, United Kingdom and New York, NY, USA, 465570, 2013.

Cowen, G. J.: Social and environmental interaction in urban wetlands, Burns Bog Conservation Society, 2015.

Crawford, B., Christen, A., and Ketler, R.: Processing and quality control procedures of turbulent flux measurements during the Vancouver EPiCC experiment, The University of British Columbia, 2013.

Crill, P., Bartlett, K., and Roulet, N.: Methane flux from boreal peatlands, International workshop on carbon cycling in boreal peatlands and climatic change, Hyytiaelae, Finland, 10, 1992.

D’Acunha, B., Johnson, M. S., Lee, S.-C., and Christen, A.: Carbon fluxes in dissolved and gaseous forms for a restored peatland in British Columbia, Canada: Net ecosystem carbon balance (NECB) determined using eddy covariance for $\mathrm{CO}_{2}$ and $\mathrm{CH}_{4}$ and dissolved C fluxes, 2016 AGU Fall meeting, San Francisco, 2016.

Davidson, E. A., Savage, K., Verchot, L. V., and Navarro, R.: Minimizing artifacts and biases in chamber-based measurements of soil respiration, Agr. Forest Meteorol., 113, 21-37, 2002.

Dise, N. B., Gorham, E., and Verry, E. S.: Environmental factors controlling methane emissions from peatlands in northern Minnesota, J. Geophys. Res.-Atmos., 98, 10583-10594, 1993.

Drösler, M., Freibauer, A., Christensen, T. R., and Friborg, T.: Observations and Status of Peatland Greenhouse Gas Emissions in Europe, in: The Continental-Scale Greenhouse Gas Balance of 
Europe, edited by: Dolman, A. J., Valentini, R., and Freibauer, A., Springer New York, New York, NY, 243-261, 2008.

Edwards, N. T.: Effects of Temperature and Moisture on Carbon Dioxide Evolution in a Mixed Deciduous Forest Floor1, Soil Sci. Soc. Am. J., 39, 361-365, 1975.

Ellis, T., Hill, P. W., Fenner, N., Williams, G. G., Godbold, D., and Freeman, C.: The interactive effects of elevated carbon dioxide and water table draw-down on carbon cycling in a Welsh ombrotrophic bog, Ecol. Eng., 35, 978-986, 2009.

Falge, E., Baldocchi, D., Olson, R., Anthoni, P., Aubinet, M., Bernhofer, C., Burba, G., Ceulemans, R., Clement, R., Dolman, H., Granier, A., Gross, P., Grunwald, T., Hollinger, D., Jensen, N. O., Katul, G., Keronen, P., Kowalski, A., Lai, C. T., Law, B. E., Meyers, T., Moncrieff, J., Moors, E., Munger, J. W., Pilegaard, K., Rannik, U., Rebmann, C., Suyker, A., Tenhunen, J., Tu, K., Verma, S., Vesala, T., Wilson, K., and Wofsy, S.: Gap filling strategies for defensible annual sums of net ecosystem exchange, Agr. Forest Meteorol., 107, 43-69, 2001.

Farquhar, G. D., von Caemmerer, S., and Berry, J. A.: A biochemical model of photosynthetic $\mathrm{CO}_{2}$ assimilation in leaves of $\mathrm{C} 3$ species, Planta, 149, 78-90, 1980.

Finér, L. and Laine, J.: Root dynamics at drained peatland sites of different fertility in southern Finland, Plant Soil, 201, 27-36, 1998.

Flanagan, L. B. and Syed, K. H.: Stimulation of both photosynthesis and respiration in response to warmer and drier conditions in a boreal peatland ecosystem, Glob. Change Biol., 17, 2271-2287, 2011.

Foken, T., Gockede, M., Mauder, M., Mahrt, L., Amiro, B. D., and Munger, J. W.: Post-field data quality control, in: Handbook of Micrometeorology: A Guide for Surface Flux Measurements, edited by: Lee, X., Kluwer Academic Publishers, Dordrecht, 2004.

Fortuniak, K., Pawlak, W., Bednorz, L., Grygoruk, M., Siedlecki, M., and Zieliński, M.: Methane and carbon dioxide fluxes of a temperate mire in Central Europe, Agr. Forest Meteorol., 232, 306-318, 2017.

Frolking, S. and Roulet, N. T.: Holocene radiative forcing impact of northern peatland carbon accumulation and methane emissions, Glob. Change Biol., 13, 1079-1088, 2007.

Frolking, S., Roulet, N., and Lawrence, D.: Issues Related to Incorporating Northern Peatlands into Global Climate Models, in: Carbon Cycling in Northern Peatlands, American Geophysical Union, 19-35, 2013.

Fuglestvedt, J. S., Berntsen, T. K., Godal, O., and Skodvin, T.: Climate implications of GWP-based reductions in greenhouse gas emissions, Geophys. Res. Lett., 27, 409-412, 2000.

Gaveau, D. L. A., Salim, M. A., Hergoualc'h, K., Locatelli, B., Sloan, S., Wooster, M., Marlier, M. E., Molidena, E., Yaen, H., DeFries, R., Verchot, L., Murdiyarso, D., Nasi, R., Holmgren, P., and Sheil, D.: Major atmospheric emissions from peat fires in Southeast Asia during non-drought years: evidence from the 2013 Sumatran fires, Scientific Reports, 4, 6112, 2014.

Godwin, C. M., McNamara, P. J., and Markfort, C. D.: Evening methane emission pulses from a boreal wetland correspond to convective mixing in hollows, J. Geophys. Res.-Biogeo., 118, 994-1005, 2013.

Goodrich, J. P., Campbell, D. I., Roulet, N. T., Clearwater, M. J., and Schipper, L. A.: Overriding control of methane flux temporal variability by water table dynamics in a Southern Hemisphere, raised bog, J. Geophys. Res.-Biogeo., 120, 819-831, 2015.

Griffis, T. J., Black, T. A., Morgenstern, K., Barr, A. G., Nesic, Z., Drewitt, G. B., GaumontGuay, D., and McCaughey, J. H.: Ecophysiological controls on the carbon balances of three southern boreal forests, Agr. Forest Meteorol., 117, 53-71, https://doi.org/10.1016/S0168-1923(03)00023-6, 2003.

Heathwaite, A. L. and Göttlich, K.: Mires: process, exploitation, and conservation, Wiley, Chichester, 1993.

Hebda, R. J., Gustavson, K., Golinski, K., and Calder, A. M.: Burns Bog Ecosystem Review Synthesis for Burns Bog, Fraser River Delta, South-western British Columbia, Canada, Environmental Assessment Office, Victoria, B.C., 2000.

Helfter, C., Campbell, C., Dinsmore, K. J., Drewer, J., Coyle, M., Anderson, M., Skiba, U., Nemitz, E., Billett, M. F., and Sutton, M. A.: Drivers of long-term variability in $\mathrm{CO}_{2}$ net ecosystem exchange in a temperate peatland, Biogeosciences, 12, 1799-1811, https://doi.org/10.5194/bg-12-1799-2015, 2015.

Hendriks, D. M. D., van Huissteden, J., Dolman, A. J., and van der Molen, M. K.: The full greenhouse gas balance of an abandoned peat meadow, Biogeosciences, 4, 411-424, https://doi.org/10.5194/bg-4-411-2007, 2007.

Herbst, M., Friborg, T., Ringgaard, R., and Soegaard, H.: Interpreting the variations in atmospheric methane fluxes observed above a restored wetland, Agr. Forest Meteorol., 151, 841-853, https://doi.org/10.1016/j.agrformet.2011.02.002, 2011.

Herbst, M., Friborg, T., Schelde, K., Jensen, R., Ringgaard, R., Vasquez, V., Thomsen, A. G., and Soegaard, H.: Climate and site management as driving factors for the atmospheric greenhouse gas exchange of a restored wetland, Biogeosciences, 10, 39-52, https://doi.org/10.5194/bg-10-39-2013, 2013.

Howie, S. A., Whitfield, P. H., Hebda, R. J., Munson, T. G., Dakin, R. A., and Jeglum, J. K.: Water Table and Vegetation Response to Ditch Blocking: Restoration of a Raised Bog in Southwestern British Columbia, Can. Water Resour. J., 34, 381-392, 2009.

Humphreys, E. R., Charron, C., Brown, M., and Jones, R.: Two Bogs in the Canadian Hudson Bay Lowlands and a Temperate Bog Reveal Similar Annual Net Ecosystem Exchange of $\mathrm{CO}_{2}$, Arct. Antarct. Alp. Res., 46, 103-113, 2014.

IPCC: Climate Change 2014: Impacts, Adaptation, and Vulnerability. Part A: Global and Sectoral Aspects. Contribution of Working Group II to the Fifth Assessment Report of the Intergovernmental Panel on Climate Change, edited by: Field, C. B., Barros, V. R., Dokken, D. J., Mach, K. J., Mastrandrea, M. D., Bilir, T. E., Chatterjee, M., Ebi, K. L., Estrada, Y. O., Genova, R. C., Girma, B., Kissel, E. S., Levy, A. N., MacCracken, S., Mastrandrea, P. R., and White, L. L., Cambridge University Press, Cambridge, UK and New York, NY, USA, 2014.

Jackowicz-Korczynski, M., Christensen, T. R., Bäckstrand, K., Crill, P., Friborg, T., Mastepanov, M., and Ström, L.: Annual cycle of methane emission from a subarctic peatland, J. Geophys. Res.-Biogeo., 115, G02009, https://doi.org/10.1029/2008JG000913, 2010.

Järveoja, J., Peichl, M., Maddison, M., Soosaar, K., Vellak, K., Karofeld, E., Teemusk, A., and Mander, Ü.: Impact of water table level on annual carbon and greenhouse gas balances of a restored peat extraction area, Biogeosciences, 13, 2637-2651, https://doi.org/10.5194/bg-13-2637-2016, 2016. 
Joosten, H.: Peatlands: Guidance for Climate Change Mitigation Through Conservation, Rehabilitation and Sustainable Use, Food and Agriculture Organization of the United Nations, Rome, Italy, 2012.

Juszczak, R., Humphreys, E., Acosta, M., Michalak-Galczewska, M., Kayzer, D., and Olejnik, J.: Ecosystem respiration in a heterogeneous temperate peatland and its sensitivity to peat temperature and water table depth, Plant Soil, 366, 505-520, 2013.

Juutinen, S., Alm, J., Larmola, T., Saarnio, S., Martikainen, P. J., and Silvola, J.: Stand-specific diurnal dynamics of $\mathrm{CH}_{4}$ fluxes in boreal lakes: Patterns and controls, J. Geophys. Res.-Atmos., 109, D19313, https://doi.org/10.1029/2004JD004782, 2004.

Karki, S., Elsgaard, L., Kandel, T. P., and Lærke, P. E.: Carbon balance of rewetted and drained peat soils used for biomass production: a mesocosm study, GCB Bioenergy, 8, 969-980, 2016.

Kleinen, T., Brovkin, V., von Bloh, W., Archer, D., and Munhoven, G.: Holocene carbon cycle dynamics, Geophys. Res. Lett., 37, L02705, https://doi.org/10.1029/2009GL041391, 2010.

Kljun, N., Black, T. A., Griffis, T. J., Barr, A. G., Gaumont-Guay, D., Morgenstern, K., McCaughey, J. H., and Nesic, Z.: Response of Net Ecosystem Productivity of Three Boreal Forest Stands to Drought, Ecosystems, 9, 1128-1144, 2006.

Knorr, K.-H., Lischeid, G., and Blodau, C.: Dynamics of redox processes in a minerotrophic fen exposed to a water table manipulation, Geoderma, 153, 379-392, https://doi.org/10.1016/j.geoderma.2009.08.023, 2009.

Knox, S. H., Sturtevant, C., Matthes, J. H., Koteen, L., Verfaillie, J., and Baldocchi, D.: Agricultural peatland restoration: effects of land-use change on greenhouse gas $\left(\mathrm{CO}_{2}\right.$ and $\left.\mathrm{CH}_{4}\right)$ fluxes in the Sacramento-San Joaquin Delta, Glob. Change Biol., 21, 750765, 2015.

Koehler, A.-K., Sottocornola, M., and Kiely, G.: How strong is the current carbon sequestration of an Atlantic blanket bog?, Glob. Change Biol., 17, 309-319, 2011.

Koh, H.-S., Ochs, C. A., and Yu, K.: Hydrologic gradient and vegetation controls on $\mathrm{CH}_{4}$ and $\mathrm{CO}_{2}$ fluxes in a spring-fed forested wetland, Hydrobiologia, 630, 271-286, 2009.

Komulainen, V.-M., Tuittila, E.-S., Vasander, H., and Laine, J.: Restoration of Drained Peatlands in Southern Finland: Initial Effects on Vegetation Change and $\mathrm{CO}_{2}$ Balance, J. Appl. Ecol., 36, 634-648, 1999.

Kormann, R. and Meixner, F. X.: An analytical footprint model for non-neutral stratification, Bound.-Lay. Meteorol., 99, 207-224, 2001.

Krishnan, P., Black, T. A., Grant, N. J., Barr, A. G., Hogg, E. H., Jassal, R. S., and Morgenstern, K.: Impact of changing soil moisture distribution on net ecosystem productivity of a boreal aspen forest during and following drought, Agr. Forest Meteorol., 139, 208-223, https://doi.org/10.1016/j.agrformet.2006.07.002, 2006.

Krishnan, P., Black, T. A., Jassal, R. S., Chen, B., and Nesic, Z.: Interannual variability of the carbon balance of three different-aged Douglas-fir stands in the Pacific Northwest, J. Geophys. Res.Biogeo., 114, G04011, https://doi.org/10.1029/2008JG000912, 2009.

Kroon, P. S., Schrier-Uijl, A. P., Hensen, A., Veenendaal, E. M., and Jonker, H. J. J.: Annual balances of $\mathrm{CH}_{4}$ and $\mathrm{N}_{2} \mathrm{O}$ from a managed fen meadow using eddy covariance flux measurements, Eur. J. Soil Sci., 61, 773-784, 2010.
Lafleur, P. M., Roulet, N. T., and Admiral, S. W.: Annual cycle of $\mathrm{CO}_{2}$ exchange at a bog peatland, J. Geophys. Res.-Atmos., 106, 3071-3081, 2001.

Lafleur, P. M., Hember, R. A., Admiral, S. W., and Roulet, N. T.: Annual and seasonal variability in evapotranspiration and water table at a shrub-covered bog in southern Ontario, Canada, Hydrol. Process., 19, 3533-3550, 2005.

Lai, D. Y. F., Roulet, N. T., and Moore, T. R.: The spatial and temporal relationships between $\mathrm{CO}_{2}$ and $\mathrm{CH}_{4}$ exchange in a temperate ombrotrophic bog, Atmos. Environ., 89, 249-259, https://doi.org/10.1016/j.atmosenv.2014.02.034, 2014.

Lal, R.: Carbon sequestration, Philos. T. R. Soc. B, 363, 815-830, https://doi.org/10.1098/rstb.2007.2185, 2008.

Langeveld, C. A., Segers, R., Dirks, B. O. M., van den Pol-van Dasselaar, A., Velthof, G. L., and Hensen, A.: Emissions of $\mathrm{CO}_{2}$, $\mathrm{CH}_{4}$ and $\mathrm{N}_{2} \mathrm{O}$ from pasture on drained peat soils in the Netherlands, in: Developments in Crop Science, edited by: Ittersum, M. K. v. and Geijn, S. C. v. d., Elsevier, 1997.

Lee, S.-C.: Annual greenhouse gas budget for a bog ecosystem undergoing restoration by rewetting, MSc, Geography, UBC, Vancovuer, 2016.

Lehner, B. and Döll, P.: Development and validation of a global database of lakes, reservoirs and wetlands, J. Hydrol., 296, 1-22, https://doi.org/10.1016/j.jhydrol.2004.03.028, 2004.

Levy, P. E. and Gray, A.: Greenhouse gas balance of a semi-natural peatbog in northern Scotland, Environ. Res. Lett., 10, 094019, https://doi.org/10.1088/1748-9326/10/9/094019, 2015.

Limpens, J., Berendse, F., Blodau, C., Canadell, J. G., Freeman, C., Holden, J., Roulet, N., Rydin, H., and Schaepman-Strub, G.: Peatlands and the carbon cycle: from local processes to global implications - a synthesis, Biogeosciences, 5, 1475-1491, https://doi.org/10.5194/bg-5-1475-2008, 2008.

Lloyd, J. and Taylor, J. A.: On the Temperature Dependence of Soil Respiration, Funct. Ecol., 8, 315-323, 1994.

Long, K. D., Flanagan, L. B., and Cai, T.: Diurnal and seasonal variation in methane emissions in a northern Canadian peatland measured by eddy covariance, Glob. Change Biol., 16, 2420-2435, 2010.

Lund, M., Lafleur, P. M., Roulet, N. T., Lindroth, A., Christensen, T. R., Aurela, M., Chojnicki, B. H., Flanagan, L. B., Humphreys, E. R., Laurila, T., Oechel, W. C., Olejnik, J., Rinne, J., Schubert, P. E. R., and Nilsson, M. B.: Variability in exchange of $\mathrm{CO}_{2}$ across 12 northern peatland and tundra sites, Glob. Change Biol., 16, 2436-2448, 2010.

Madrone Consultants Ltd.: Burns Bog Ecosystem Review, Plants and Plant Communities, Madrone Consultants Ltd., Duncan, BC, 1999.

McVeigh, P., Sottocornola, M., Foley, N., Leahy, P., and Kiely, G.: Meteorological and functional response partitioning to explain interannual variability of $\mathrm{CO}_{2}$ exchange at an Irish Atlantic blanket bog, Agr. Forest Meteorol., 194, 8-19, 2014.

Metro Vancouver: Burns Bog Ecological Conservancy Area Management Plan, Metro Vancouver, Burnaby, BC, 2007.

Minkkinen, K. and Laine, J.: Long-term effect of forest drainage on the peat carbon stores of pine mires in Finland, Can. J. Forest Res., 28, 1267-1275, 1998.

Mitsch, W., Nahlik, A., Wolski, P., Bernal, B., Zhang, L., and Ramberg, L.: Tropical wetlands: seasonal hydrologic pulsing, carbon 
sequestration, and methane emissions, Wetl. Ecol. Manag., 18, 573-586, 2010.

Moore, P. D.: The future of cool temperate bogs, Environ. Conserv., 29, 3-20, 2002.

Nahlik, A. M. and Mitsch, W. J.: Methane Emissions From Created Riverine Wetlands, Wetlands, 30, 783-793, https://doi.org/10.1007/s13157-010-0038-6, 2010

Neter, J., Wasserman, W., and Whitmore, G. A.: Applied Statistics, Allyn \& Bacon, Newton, Massachusetts, 1988.

Neubauer, S. C. and Megonigal, J. P.: Moving Beyond Global Warming Potentials to Quantify the Climatic Role of Ecosystems, Ecosystems, 18, 1000-1013, 2015.

Nicolini, G., Castaldi, S., Fratini, G., and Valentini, R.: A literature overview of micrometeorological $\mathrm{CH}_{4}$ and $\mathrm{N}_{2} \mathrm{O}$ flux measurements in terrestrial ecosystems, Atmos. Environ., 81, 311-319, 2013

Ögren, E. and Evans, J. R.: Photosynthetic light-response curves, Planta, 189, 182-190, 1993.

Olson, D. M., Griffis, T. J., Noormets, A., Kolka, R., and Chen, J.: Interannual, seasonal, and retrospective analysis of the methane and carbon dioxide budgets of a temperate peatland, J. Geophys. Res.-Biogeo., 118, 226-238, https://doi.org/10.1002/jgrg.20031, 2013.

Page, S. E., Siegert, F., Rieley, J. O., Boehm, H.-D. V., Jaya, A., and Limin, S.: The amount of carbon released from peat and forest fires in Indonesia during 1997, Nature, 420, 61-65, 2002.

Paul-Limoges, E., Black, T. A., Christen, A., Nesic, Z., and Jassal, R. S.: Effect of clearcut harvesting on the carbon balance of a Douglas-fir forest, Agr. Forest Meteorol., 203, 30-42, https://doi.org/10.1016/j.agrformet.2014.12.010, 2015.

Peichl, M., Öquist, M., Löfvenius, M. O., Ilstedt, U., Sagerfors, J., Grelle, A., Lindroth, A., and Nilsson, M.: A 12-year record reveals pre-growing season temperature and water table level threshold effects on the net carbon dioxide exchange in a boreal fen, Environ. Res. Lett., 9, 055006, https://doi.org/10.1088/17489326/9/5/055006, 2014

Pelletier, L., Strachan, I. B., Roulet, N. T., Garneau, M., and Wischnewski, K.: Effect of open water pools on ecosystem scale surface-atmosphere carbon dioxide exchange in a boreal peatland, Biogeochemistry, 124, 291-304, 2015.

Petrescu, A. M. R., Lohila, A., Tuovinen, J.-P., Baldocchi, D. D., Desai, A. R., Roulet, N. T., Vesala, T., Dolman, A. J., Oechel, W. C., Marcolla, B., Friborg, T., Rinne, J., Matthes, J. H., Merbold, L., Meijide, A., Kiely, G., Sottocornola, M., Sachs, T., Zona, D., Varlagin, A., Lai, D. Y. F., Veenendaal, E., Parmentier, F.-J. W., Skiba, U., Lund, M., Hensen, A., van Huissteden, J., Flanagan, L. B., Shurpali, N. J., Grünwald, T., Humphreys, E. R., JackowiczKorczyński, M., Aurela, M. A., Laurila, T., Grüning, C., Corradi, C. A. R., Schrier-Uijl, A. P., Christensen, T. R., Tamstorf, M. P., Mastepanov, M., Martikainen, P. J., Verma, S. B., Bernhofer, C., and Cescatti, A.: The uncertain climate footprint of wetlands under human pressure, P. Natl. Acad. Sci. USA, 112, 4594-4599, 2015

Price, J. S. and Waddington, J. M.: Advances in Canadian wetland hydrology an biogeochemistry, Hydrol. Process., 14, 1579-1589, 2000.

Reichstein, M., Falge, E., Baldocchi, D., Papale, D., Aubinet, M., Berbigier, P., Bernhofer, C., Buchmann, N., Gilmanov, T., Granier, A., Grünwald, T., Havránková, K., Ilvesniemi, H.,
Janous, D., Knohl, A., Laurila, T., Lohila, A., Loustau, D., Matteucci, G., Meyers, T., Miglietta, F., Ourcival, J.-M., Pumpanen, J., Rambal, S., Rotenberg, E., Sanz, M., Tenhunen, J., Seufert, G., Vaccari, F., Vesala, T., Yakir, D., and Valentini, R.: On the separation of net ecosystem exchange into assimilation and ecosystem respiration: review and improved algorithm, Glob. Change Biol., 11, 1424-1439, 2005

Richards, B. and Craft, C. B.: Greenhouse Gas Fluxes from Restored Agricultural Wetlands and Natural Wetlands, Northwestern Indiana, in: The Role of Natural and Constructed Wetlands in Nutrient Cycling and Retention on the Landscape, edited by: Vymazal, J., Springer International Publishing, Cham, 2015.

Rinne, J., Riutta, T., Pihlatie, M., Aurela, M., Haapanala, S., Tuovinen, J.-P., Tuittila, E.-S., and Vesala, T.: Annual cycle of methane emission from a boreal fen measured by the eddy covariance technique, Tellus B, 59, 449-457, https://doi.org/10.1111/j.16000889.2007.00261.x, 2007.

Rochefort, L., Campeau, S., and Bugnon, J.-L.: Does prolonged flooding prevent or enhance regeneration and growth of Sphagnum?, Aquat. Bot., 74, 327-341, 2002.

Romanowicz, E. A., Siegel, D. I., Chanton, J. P., and Glaser, P. H.: Temporal variations in dissolved methane deep in the Lake Agassiz Peatlands, Minnesota, Global Biogeochem. Cy., 9, 197-212, doi10.1029/95GB00634, 1995.

Roulet, N.: Peatlands, carbon storage, greenhouse gases, and the Kyoto Protocol: Prospects and significance for Canada, Wetlands, 20, 605-615, 2000.

Roulet, N. T., Ash, R., Quinton, W., and Moore, T.: Methane flux from drained northern peatlands: Effect of a persistent water table lowering on flux, Global Biogeochem. Cy., 7, 749-769, https://doi.org/10.1029/93GB01931, 1993.

Roulet, N. T., Lafleur, P. M., Richard, P. J. H., Moore, T. R., Humphreys, E. R., and Bubier, J.: Contemporary carbon balance and late Holocene carbon accumulation in a northern peatland, Glob. Change Biol., 13, 397-411, 2007.

Rydin, H., Jeglum, J. K., Jeglum, J. K., and Bennett, K. D.: The Biology of Peatlands, 2e, OUP Oxford, 2013.

Schipper, L. A. and Reddy, K. R.: Methane Production and Emissions from Four Reclaimed and Pristine Wetlands of Southeastern United States, Soil Sci. Soc. Am. J., 58, 1270-1275, 1994.

Schrier-Uijl, A. P., Kroon, P. S., Leffelaar, P. A., van Huissteden, J. C., Berendse, F., and Veenendaal, E. M.: Methane emissions in two drained peat agro-ecosystems with high and low agricultural intensity, Plant Soil, 329, 509-520, 2010.

Schrier-Uijl, A. P., Kroon, P. S., Hendriks, D. M. D., Hensen, A., Van Huissteden, J., Berendse, F., and Veenendaal, E. M.: Agricultural peatlands: towards a greenhouse gas sink - a synthesis of a Dutch landscape study, Biogeosciences, 11, 4559-4576, https://doi.org/10.5194/bg-11-4559-2014, 2014.

Shannon, R. and White, J.: A three-year study of controls on methane emissions from two Michigan peatlands, Biogeochemistry, 27, 35-60, 1994.

Shurpali, N. J., HyvÖNen, N. P., Huttunen, J. T., Biasi, C., NykÄNen, H., Pekkarinen, N., and Martikainen, P. J.: Bare soil and reed canary grass ecosystem respiration in peat extraction sites in Eastern Finland, Tellus B, 60, 200-209, 2008.

Smith, S. J. and Wigley, M. L.: Global Warming Potentials: 1. Climatic Implications of Emissions Reductions, Climatic Change, 44, 445-457, 2000. 
Song, C., Xu, X., Tian, H., and Wang, Y.: Ecosystem-atmosphere exchange of $\mathrm{CH}_{4}$ and $\mathrm{N}_{2} \mathrm{O}$ and ecosystem respiration in wetlands in the Sanjiang Plain, Northeastern China, Glob. Change Biol., 15, 692-705, https://doi.org/10.1111/j.1365-2486.2008.01821.x, 2009.

Sottocornola, M. and Kiely, G.: Hydro-meteorological controls on the $\mathrm{CO}_{2}$ exchange variation in an Irish blanket bog, Agr. Forest Meteorol., 150, 287-297, 2010.

Strack, M. and Zuback, Y. C. A.: Annual carbon balance of a peatland $10 \mathrm{yr}$ following restoration, Biogeosciences, 10, 2885-2896, https://doi.org/10.5194/bg-10-2885-2013, 2013.

Strack, M., Waddington, J. M., Rochefort, L., and Tuittila, E. S.: Response of vegetation and net ecosystem carbon dioxide exchange at different peatland microforms following water table drawdown, J. Geophys. Res.-Biogeo., 111, G02006, https://doi.org/10.1029/2005JG000145, 2006.

Sun, L., Song, C., Miao, Y., Qiao, T., and Gong, C.: Temporal and spatial variability of methane emissions in a northern temperate marsh, Atmos. Environ., 81, 356-363, 2013.

Treat, C. C., Bubier, J. L., Varner, R. K., and Crill, P. M.: Timescale dependence of environmental and plant-mediated controls on $\mathrm{CH}_{4}$ flux in a temperate fen, J. Geophys. Res.-Biogeo., 112, G01014, https://doi.org/10.1029/2006JG000210, 2007.

Tuittila, E.-S., Komulainen, V.-M., Vasander, H., Nykänen, H., Martikainen, P. J., and Laine, J.: Methane dynamics of a restored cutaway peatland, Glob. Change Biol., 6, 569-581, 2000.

Turetsky, M. R., Kotowska, A., Bubier, J., Dise, N. B., Crill, P., Hornibrook, E. R. C., Minkkinen, K., Moore, T. R., MyersSmith, I. H., Nykänen, H., Olefeldt, D., Rinne, J., Saarnio, S., Shurpali, N., Tuittila, E.-S., Waddington, J. M., White, J. R., Wickland, K. P., and Wilmking, M.: A synthesis of methane emissions from 71 northern, temperate, and subtropical wetlands, Glob. Change Biol., 20, 2183-2197, 2014.

Urbanová, Z., Bárta, J., and Picek, T.: Methane Emissions and Methanogenic Archaea on Pristine, Drained and Restored Mountain Peatlands, Central Europe, Ecosystems, 16, 664-677, https://doi.org/10.1007/s10021-013-9637-4, 2013.

van der Werf, G. R., Randerson, J. T., Collatz, G. J., Giglio, L., Kasibhatla, P. S., Arellano, A. F., Olsen, S. C., and Kasischke, E. S.: Continental-Scale Partitioning of Fire Emissions During the 1997 to 2001 El Niño/La Niña Period, Science, 303, 73-76, 2004.

Waddington, J. M. and Roulet, N. T.: Carbon balance of a boreal patterned peatland, Glob. Change Biol., 6, 87-97, 2000.
Waddington, J. M., Strack, M., and Greenwood, M. J.: Toward restoring the net carbon sink function of degraded peatlands: Short-term response in $\mathrm{CO}_{2}$ exchange to ecosystemscale restoration, J. Geophys. Res.-Biogeo., 115, G01008, https://doi.org/10.1029/2009JG001090, 2010.

Walter, B. P. and Heimann, M.: A process-based, climate-sensitive model to derive methane emissions from natural wetlands: Application to five wetland sites, sensitivity to model parameters, and climate, Global Biogeochem. Cy., 14, 745-765, https://doi.org/10.1029/1999GB001204, 2000.

Wang, Z.-P. and Han, X.-G.: Diurnal variation in methane emissions in relation to plants and environmental variables in the Inner Mongolia marshes, Atmos. Environ., 39, 6295-6305, 2005.

Wania, R., Ross, I., and Prentice, I. C.: Integrating peatlands and permafrost into a dynamic global vegetation model: 1. Evaluation and sensitivity of physical land surface processes, Global Biogeochem. Cy., 23, GB3014, https://doi.org/10.1029/2008GB003412, 2009.

Weltzin, J. F., Pastor, J., Harth, C., Bridgham, S. D., Updegraff, K., and Chapin, C. T.: Response of bog and fen plant communities to warming and water-table manipulations, Ecology, 81, 34643478, 2000.

Whiting, G. J. and Chanton, J. P.: Greenhouse carbon balance of wetlands: methane emission versus carbon sequestration, 53, 521-528, https://doi.org/10.1034/j.1600-0889.2001.530501.x, 2001.

Wilson, D., Farrell, C., Mueller, C., Hepp, S., and Renou-Wilson, F.: Rewetted industrial cutaway peatlands in western Ireland: a prime location for climate change mitigation?, Mires and Peat, $11,1,2013$.

Windsor, J., Moore, T. R., and Roulet, N. T.: Episodic fluxes of methane from subarctic fens, Can. J. Soil Sci., 72, 441-452, https://doi.org/10.4141/cjss92-037, 1992.

Wisniewski, J. and Sampson, R. N.: Terrestrial Biospheric Carbon Fluxes Quantification of Sinks and Sources of $\mathrm{CO}_{2}$, Springer Netherlands, 2012.

Yu, Z., Loisel, J., Brosseau, D. P., Beilman, D. W., and Hunt, S. J.: Global peatland dynamics since the Last Glacial Maximum, Geophys. Res. Lett., 37, L13402, https://doi.org/10.1029/2010GL043584, 2010. 